\title{
ON THE ROLE OF THE CHIEF RISK OFFICER AND THE RISK COMMITTEE IN INSURING FINANCIAL INSTITUTIONS AGAINST LITIGATION
}

\author{
Arash Amoozegar
}

\author{
A Thesis \\ In \\ The John Molson School of Business
}

\author{
Presented in Partial Fulfillment of the Requirements \\ for the Degree of Master of Science (Administration) at \\ Concordia University \\ Montreal, Quebec, Canada
}

August 2013

(C) Arash Amoozegar, 2013 


\section{CONCORDIA UNIVERSITY School of Graduate Studies}

This is to certify that the thesis prepared

By: $\quad$ Arash Amoozegar

Entitled: $\quad$ On the Role of the Chief Risk Officer and the Risk Committee in Insuring Financial Institutions against Litigation

and submitted in partial fulfillment of the requirements for the degree of Master of Science (Administration)

complies with the regulations of the University and meets the accepted standards with respect to originality and quality.

Signed by the final examining committee:

\begin{tabular}{ll} 
Dennis Kira & Chair \\
\hline Frederick Davis & Examiner \\
\hline Rahul Ravi & Examiner \\
\hline Thomas Walker & \\
\hline & Supervisor
\end{tabular}

Approved by

Chair of Department or Graduate Program Director

Dean of Faculty

Date $\quad$ August 8, 2013 


\title{
ABSTRACT \\ ON THE ROLE OF THE CHIEF RISK OFFICER AND THE RISK COMMITTEE IN INSURING FINANCIAL INSTITUTIONS AGAINST LITIGATION
}

\begin{abstract}
Arash Amoozegar
Can Chief Risk Officers (CROs) act as insurance against litigation risks in financial institutions? In most financial institutions, CROs and their risk management staff fulfill a key role in managing risk exposures, yet their lack of involvement in the governance of banks has been cited as an influential factor that contributed to management team failure and the financial crisis of 2007-2008. A variety of legislative and regulatory bodies have pressured financial firms to improve their risk governance structures to better weather any potential future crises. Assuming that CROs are indeed given sufficient power to influence the corporate governance of financial institutions, can they provide these firms with the promised benefits? To partially answer this question, we consider one of the final outcomes of risky behavior: shareholder litigation. By comparing the risk governance characteristics of sued firms with their non-sued peers, we show that proper risk governance reduces a firm's litigation probability. We accomplish this by using principal component analysis and by constructing a single measure that captures various aspects of risk management in a firm. In addition, we show that the addition of our risk management factor to models that have been previously proposed in the literature improves the accuracy of those models in identifying companies that are most susceptible to class action lawsuits.
\end{abstract}




\section{ACKNOWLEDGEMENTS AND DEDICATIONS}

I would like to express my special thanks and gratitude to my supervisor, Dr. Thomas Walker, who gave me the golden opportunity to benefit from his knowledge and experience during this study in spite of his busy schedule. I am truly thankful to him for his advice and encouragement.

Secondly, I would like to thank Dr. Frederick Davis, Dr. Rahul Ravi, and Dr. Alexandra Dawson who were and will be my true role models in conducting research.

Thirdly, I would like to thank my parents who supported me during different stages of this study and my significant other who listened to all my complaints and gripes very calmly and still believed in me. Hail to my superhuman.

Thanks again to all who were there for me. 


\section{TABLE OF CONTENTS}

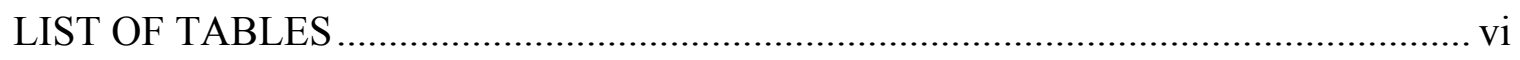

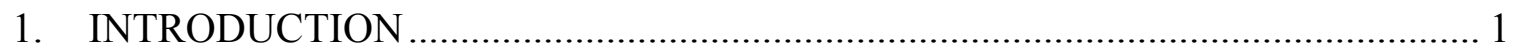

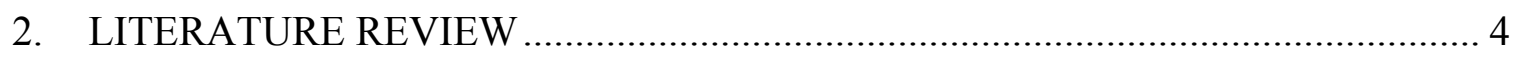

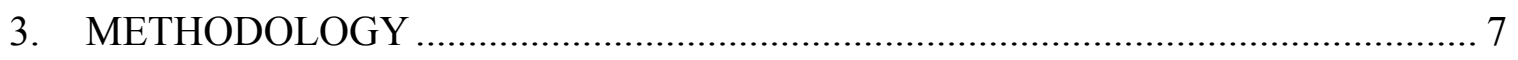

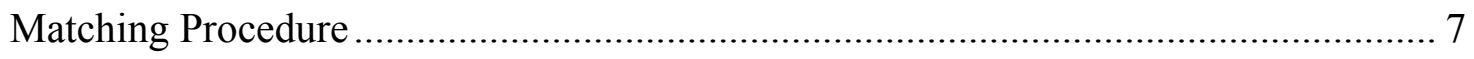

Principal Component Analysis ............................................................................ 9

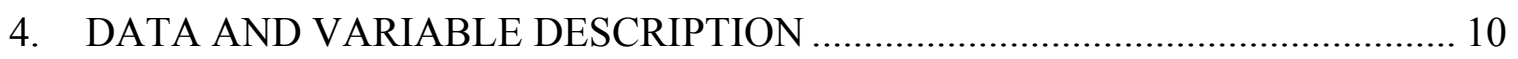

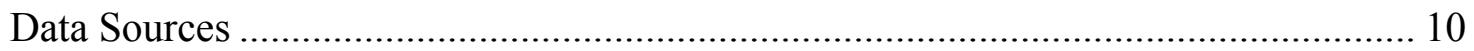

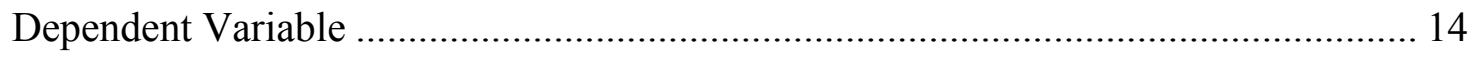

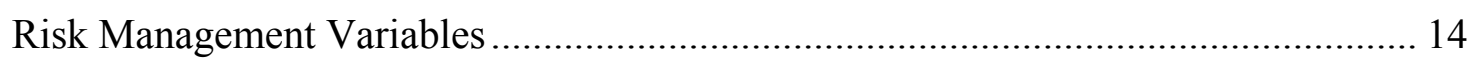

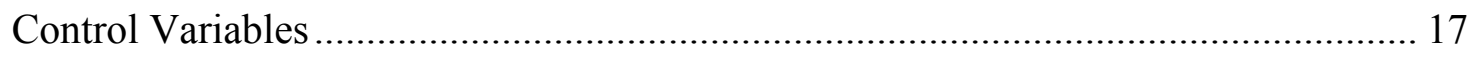

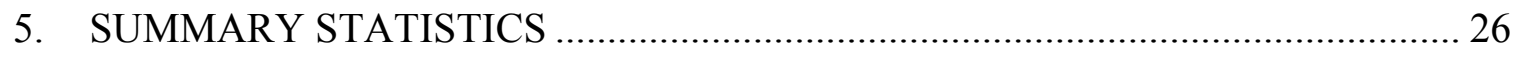

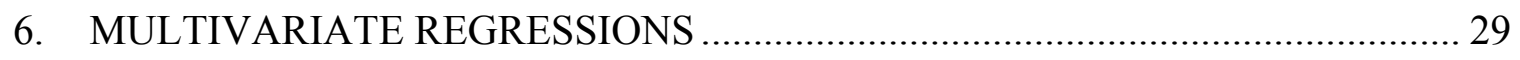

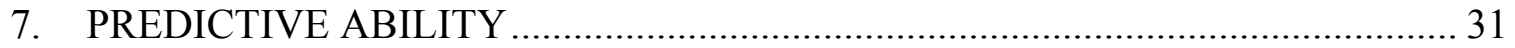

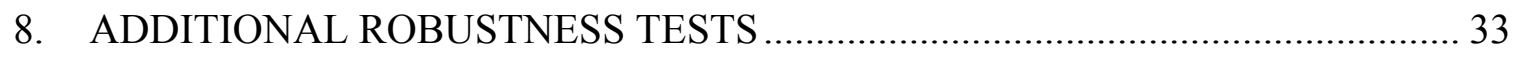

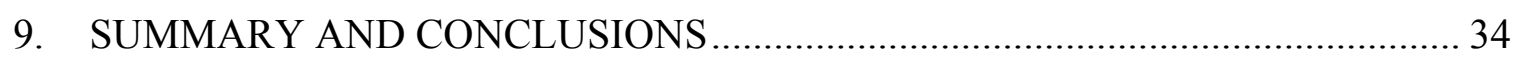

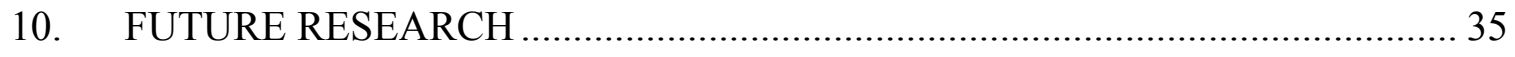

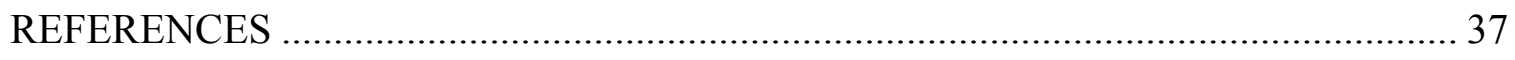




\section{LIST OF TABLES}

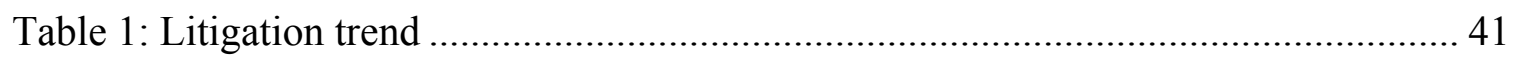

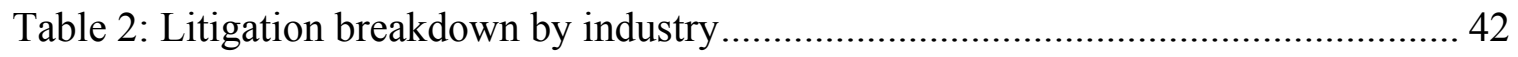

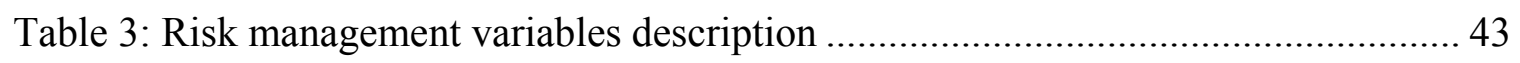

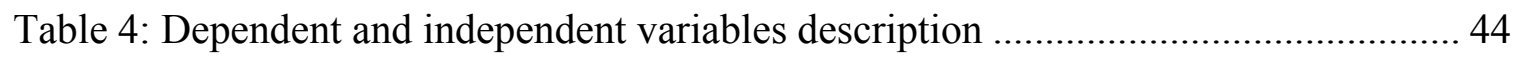

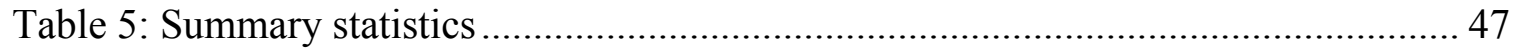

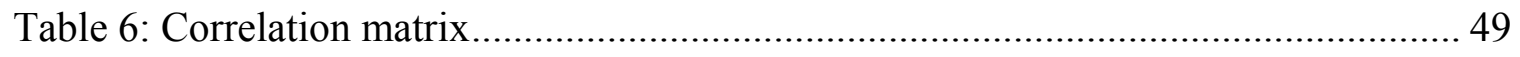

Table 7: Multivariate regression results for one year lagged risk management factor..... 50

Table 8: Multivariate regression results for three-year average risk management factor. 52

Table 9: Predictive ability of models with/without the risk management factor............. 54 


\section{INTRODUCTION}

"Risk is chemistry, it's not particle physics. You cannot separate the risks."

Mikes (2010)

The financial crisis of 2007-2008 put a spotlight on the risk management practices of financial institutions. In the aftermath of the crisis, academics, regulators, and practitioners alike have raised concerns regarding the role and authority of risk officers in the hierarchy structure and decision-making process of financial institutions (Kirkpatrick, 2009). The Basel Committee (Basel Committee on Banking Supervision, 2012) and the Institute of International Finance (Green and Jennings-Mares, 2008) are among many regulatory authorities and industry groups that have requested improvements in the risk oversight by financial institutions.

Since its inception, the so-called Enterprise Risk Management (ERM) system has evolved into the standard tool through which organizations manage their vast risk exposures and try to seize opportunities. Naturally, it has become the focus of many practitioner and academically oriented discussions in recent years. Many organizations have started to realize the value and importance of ERM and are taking measures to implement it into their business. Universities and various certification bodies have devoted specialized educational programs for this emerging field. Similarly, consulting firms have responded to the heightened number of requests by their customers by establishing specialized consulting units. Finally, rating agencies have incorporated ERM assessments in their company evaluation process. Given these developments, it is apparent that the financial and non-financial industry as well as regulators and academics 
put a lot of importance on a correct view towards risk and its management. Yet, despite this welcome attention, the empirical evidence regarding the effectiveness of enterprise risk management in better insuring an organization against hazards and better equipping it with appropriate tools for benefiting from opportunities is lagging behind (Hoyt and Liebenberg, 2011).

This study aims to fill this gap in the financial literature by examining the effectiveness of appropriate risk management structures and in insuring companies against shareholder litigation. Our main proposition in this study is that institutions that have a good understanding of risk and its management are more prudent in their activities and will not expose themselves to excessive risks, and if a risky situation arises - as it always does in today's volatile markets - these institutions should be well-equipped to identify them and take appropriate actions before hedging these risks either becomes too expensive or impossible. We are interested to see if there is a significant difference in the propensity to be sued between financial institutions that have implemented a strong and independent risk management function in their business and ones that do not share the same holistic view towards risk and risk management and instead engage in isolated risk management practices.

Some readers may wonder why we only focus on financial institutions. What makes the risk management function in these firms special? Risk taking and risk managing is part of the day-to-day business of financial institutions. The complexity of their operations exposes these institutions to a variety of risks. In addition, because many financial institutions engage in different business lines - many of which are not directly related to banking - they have a more complex risk profile that is considerably more 
difficult to manage. Despite legitimate demands and pressures from regulators and market participants, the evidence presented in recent studies reveals that risk management has a relatively low priority in these institutions even though their primary concern should be what risks they are facing and how they can effectively manage them. Valukas (2010) provides a case study of Lehman Brothers Holdings Inc. and shows that the firm's senior management team ignored its risk limits and disregarded the red flags pointed out by its senior risk officers. In his article, Scott (2011) notices the negative correlation between the rank of the person in a company and his understanding of the actual business of the firm. In addition, he points out the "absurdity" of firing the company's senior risk officer in a usual downsizing. By focusing our attention on financial institutions, we want to see whether we can support our proposition that a designated risk management function may serve as an insurance tool against litigation.

The contribution of this research is twofold. First, our study shows that effective risk management practices indeed provide litigation insurance to the firms that implement them. Second, this study contributes to the growing strand of studies that focus on industry-specific corporate governance practices and more specifically on the corporate governance of financial institutions. Similar to Ellul and Yerramilli (2012), we differentiate our work from other corporate governance studies by focusing on appropriate ex-ante remedies rather than ex-post remedies.

The remainder of this study is organized as follows. Section 2 provides a review of the related literature. Section 3 provides an overview of the matching method and principal component analysis technique employed in this study. Section 4 outlines our data sources and defines our variables. Summary statistics and multivariate analysis 
results are reported in Sections 5 and 6. Section 7 compares the predictive ability of models with and without a risk management factor. Section 8 presents different robustness tests. Section 9 summarizes our findings and concludes while Section 10 proposes some possible venues for future research.

\section{LITERATURE REVIEW}

Our study relates to several strands of research that explore the risk management in financial institutions by examining the impact of Enterprise Risk Management and the role of CROs in a firm's risk governance structure.

Ertugrul and Hegde (2009) explore whether rating agencies can identify firms that may be affected by governance issues in the future. Specifically, they employ probit regressions to examine whether ratings by The Corporate Library (TCL), Institutional Shareholder Services (ISS), and Governance Metrics International (GMI) can predict governance failures and potential future lawsuits. They document that overall ratings have little predictive power with respect to litigation likelihood, yet when they run tests on sub-ratings instead of overall ratings, they find that firms equipped with more shareholder friendly boards, a favorable litigation history, and some positive adjustments for capturing factors that cannot be included in the rating agencies' normal scoring scheme have a reduced likelihood of being sued.

Ellul and Yerramilli (2012) construct their own Risk Management Index (RMI) to evaluate whether an independent and strong risk management structure lowers the 
enterprise-wide risks in bank holding companies (BHCs). They hand-collect risk management data for the 74 largest BHCs and show that BHCs with a high RMI rating had a lower downside risk during the recent financial crisis. Expanding their analysis to the period 2000-2008, they show that the positive effect of strong risk controls is not limited to the crisis period and argue that, regardless of the economic climate, a proper risk management function will be effective in aligning a bank's behavior with its risk appetite.

Even though corporate governance indicators are frequently used as performance predictors, Aebi, Sabato, and Schmid (2011) show that these measures did not have any significant positive effect on banks' performance during the recent crisis. In contrast, they find that bank performance during this turbulent time can be explained by the banks' risk governance power structure as proxied by such factors as the risk committee and the CRO's line of reporting. This finding suggests that standard corporate governance measures cannot properly describe banks' atypical governance structure. In the same vein, Adams and Mehran (2002 and 2003) document significant differences between the board characteristics of BHCs and unregulated manufacturing firms and their effect on performance. Their findings further illustrate the specificity of board structure and its importance in the banking industry.

Even though the role and power of CROs in the corporate governance of financial institutions have become a subject of scrutiny following the two recent financial meltdowns, improvements in this area are still limited and a lot of work remains to be done. Mongiardino and Plath (2009) review the governance structure of large banks and note that even though these banks are involved in very complex operations and hold 
financial products that expose their balance sheet to a wide variety of risks, not all of them have a dedicated CRO with lines of reporting according to the industry's best practices or a dedicated risk committee. In many large banks, the risk-related responsibilities are given to audit committees which may be overburdened, causing the banks to compromise the risk management responsibilities.

The lack of a CRO's authority in a bank's governance structure, the inappropriate reporting lines of CROs, and the infrequency of risk management meetings are cited in various reports as contributing factors to the management failures in the recent crisis (see, for example, reports by the Bank for International Settlements (2009) and the Senior Supervisors' Group (2009)).

Many of the recommendations provided by the Basel Committee on Banking Supervision call for a better organizational structure with respect to risk management in the banking industry. In this study, we incorporate these recommendations into our analysis framework in order to assess the appropriateness of the risk management function. Pezier (2010) summarizes these recommendations into four general areas:

- Active involvement of the board of directors and the management team in risk management oversight;

- Independent functionality and sufficient resources at its disposal;

- Regular reporting to the board of directors and the management team; and

- Proper documentation and audits of the risk management processes.

In this study, we propose several proxies for identifying the existence of each of these recommendations and assess their impact on the probability of a financial 
institution becoming the subject of litigation. These proxies will be discussed in-depth below.

\section{METHODOLOGY}

This section introduces the matching methodology we employ in this study. First, we discuss the need for matching and its importance in this line of research. Next, we provide a detailed discussion of our matching procedure and of its advantages and drawbacks compared to other popular methods in the literature. Finally, we explain our approach for arriving at a single risk management factor while accounting for most of the variance in our underlying risk management proxies.

\section{Matching Procedure}

Since specific data for CRO-related characteristics and, on a broader scale, most of the risk management related data is not available in any commercial database, we manually collect them from company statements filed with the Securities and Exchange Commission (SEC). Hand-collecting the same information for the universe of non-sued institutions in our control group is not feasible. This is where matching comes in to play in our methodology.

We draw on Faulkender and Yang (2010) and Havrylchyk and Jurzyk (2011) who review and discuss the suitability of different matching methods that are frequently used in the finance literature. In corporate governance and banking context, Faulkender and Yang use Propensity Score Matching (PSM) to show that compensation committees 
choose companies with higher-paid CEOs as their compensation peer groups in order to have a justification for their CEO's compensation package. The authors control for different firm characteristics and find that CEO compensation is highly significant in determining the probability of a firm being chosen as a potential compensation peer. Havrylchyk and Jurzyk (2011) choose a matching technique which they claim helps overcome selection biases present in previous studies and provide evidence in favor of an increased profitability of acquired banks in Central and Eastern Europe in a three-year window after their acquisition.

We employ two criteria as part of our matching procedure, namely a firm's 4-digit Standard Industrial Classification (SIC) code and the natural log of its market value one year prior to the litigation date. Using SIC codes as a matching criterion is a natural choice since it enables us to compare financial firms that are in the same line of business. We use 4-digit SIC codes in our study since the characteristics of corporations in these 4digit categories significantly differ. For example, financial institutions in SIC code 6021 are nationally chartered banks while those in SIC code 6022 are state chartered. ${ }^{1}$

Employing the natural log of market capitalization as our second matching factor ensures that matched companies are of approximately similar market size and hence comparable. The natural log of market capitalization is calculated by taking the natural logarithm of the product of the firm's closing price and its number of shares outstanding at the end of its fiscal year. Since the distribution of firm size is highly skewed in our sample, we use the natural logarithm of this measure.

\footnotetext{
${ }^{1}$ The five groups of SIC codes used in our study are as follows: 6021 (national commercial banks), 6022 (state commercial banks), 6029 (commercial banks, NEC), 6035 (federally chartered savings institutions), and 6036 (not federally chartered savings institutions).
} 


\section{Principal Component Analysis}

As we will discuss later, we consider several main variables of interest in our regressions to proxy for different aspects of risk management and the CRO's power and influence in financial institutions. This process could potentially lead to the inclusion of highly correlated variables in our model. In order to alleviate this problem we will employ the Principal Component Analysis (PCA) technique and develop an artificial risk management variable $(R M)$ that accounts for most of the variance in our main variables of interest. Ellul and Yerramilli (2012) use the same methodology to create their Risk Management Index (RMI) while Callahan, Millar, and Schulman (2003) construct a "management participation index" by employing this technique. Some of the variables we use in our study are similar to the ones included in the RMI while others are new or are calculated using different methodologies. ${ }^{2}$

We believe that principal component analysis not only helps us eliminate the correlations in our independent variables and remove some of the redundancy in related variables, it also relieves us from making subjective decisions about the inclusion or exclusion of each independent risk management variable in our regression models (Tetlock, 2007). Aside from these advantages, the principal component analysis technique allows us to take a holistic view towards the risk management in a company. Instead of looking at different variables and their effects individually, we consider them as one single measure which is affected by all the risk management variables and accounts for most of the variation in independent variables. Specifically, we choose the

\footnotetext{
${ }^{2}$ The authors tried to get access to the data underlying the Risk Management Index by contacting Andrew Ellul. When we initiated the contact, Ellul and Yerramilli were in the process of "extending the RMI measure to a larger number of banks and going back to 1994". Thus, we could not use the RMI in our study.
} 
principal component with the highest eigenvalue as our artificial variable of choice. We use the PROC FACTOR procedure in SAS to perform the principal component analysis and use the resulting risk barometer to assess the effectiveness of each firm's risk management and risk governance.

The first principal component is considered to be the "best linear function of the related variables that summarizes the variation" (Callahan, Millar, and Schulman, 2003). The principal component analysis technique is devised in such a way that the first component accounts for the highest level of variation in the underlying factors. In our study, the first component captures $65 \%$ of the total variation in the variables and because the other components contribute marginally to the explanation of the total variance, we only consider the first component as the risk management factor in our analysis. Contrary to Ellul and Yerramilli (2012), who find that the proportion of CRO's total compensation to the CEO's total compensation is the most important underlying variable in the risk management index, we notice that the CRO c-suite dummy variable is the component with the highest score in our principal component analysis.

\section{DATA AND VARIABLE DESCRIPTION}

\section{Data Sources}

To construct our sample of financial institutions that were involved in a lawsuit, we searched the Securities Class Action Clearinghouse (SCAC) website ${ }^{3}$ for all class

\footnotetext{
${ }^{3}$ Accessible at: http://securities.stanford.edu.
} 
action lawsuits filed under the Securities Act of 1934 against financial service firms during a 16-year period from 1996 to $2011 .^{4}$ This database is maintained by Stanford University and provides information for 3,567 securities class action lawsuits during that time period. We implement multiple filters to form our final sample:

First, since we are only concerned about litigation against financial institutions, we only consider lawsuits against firms that operate in this industry. This reduces the size of our sample to 641 cases. Next, we filter our sample by only including firms that trade on one of the three major stock exchanges, i.e., the New York Stock Exchange (NYSE), the National Association of Securities Dealers Automated Quotations (NASDAQ), and the American Stock Exchange (AMEX). This step reduces our sample size to 518. All other cases involve firms that trade in the over-the-counter (OTC) market, as pink sheets, or were privately held at the time of the litigation.

Finally, we exclude cases that are filed under the 1933 Securities Act and allege security law violations in connection with initial public offerings (IPOs) since these cases have drastically different characteristics and because we require the companies in our sample to have information on different firm characteristics for at least three years prior to the filing date. Imposing this restriction reduces the size of our final sample to 432 observations. Table 1 provides yearly summary statistics for our sample.

As can be seen in Table 1 column 2, the number of class action lawsuits peaked in 2008 (with 79 cases) and in 2007 (with 43 cases), likely as a direct consequence of the

\footnotetext{
${ }^{4}$ I am indebted to Dr. Thomas Walker for granting me access to a hand-collected dataset of securities class action litigation cases.
} 
financial crisis. Afterwards, the number of cases started decreasing, reaching 14 cases in the final year of our sample.

Our sample of financial institutions includes a wide array of financial companies ranging from insurance companies and financial advisory firms to commercial banks and real estate corporations (with SIC codes in the range from 6000 to 6999). As noted earlier, we focus our attention on a subset of firms that specifically operate in the banking industry (with SIC codes of 6021, 6022, 6029, 6035, and 6036). Implementing this requirement reduces our sample significantly and leaves us with 119 litigation cases.

The specific data requirements of our study limit our sample and control group to firms that are covered by the Compustat and CRSP databases and that have the necessary financial data to calculate our variables for at least three years prior to the lawsuit filing date. This requirement reduces our sample size to 85 firms. Therefore, our complete dataset contains 85 observations for sued firms and 85 observations for their matched peers. Because we do not have any observations for the years 1996, 1997, and 1998, the final sample of our study contains lawsuits during a 13-year period from 1999 to 2011.

Table 1 column 3 presents the number of litigation cases against financial firms with banking operations that are included in our final sample. The numbers show a trend that is similar to that for the entire financial industry. More specifically, the number of lawsuits peaked in 2008 with 18 cases and after that we see a gradual decrease to 8 cases in the final year of our sample.

Table 2 provides a breakdown of the number of litigation cases for each of the four-digit SIC codes in our sample. Financial firms in the SIC codes 6021 (national 
commercial banks) and 6022 (state commercial banks) comprise most of our sample which is similar to the proportion of the firms from these groups in the entire financial industry sample.

The violations cited in the litigation case summaries vary significantly in our sample but similar to Peng and Röell (2008) we are able to classify them into two distinct categories, namely (1) firms sued for allegedly engaging in fraudulent behavior, and (2) firms sued for providing material misinformation in their public statements. We hypothesize that firms that empower their $\mathrm{CRO}$ will reduce the likelihood of fraudulent behavior across the firm. Certainly, this form of litigation insurance is not free of charge. As Aebi, Sabato, and Schmid (2011) point out, implementing a more rigid risk governance structure can lower the performance of banks during non-crisis market conditions.

Unfortunately, there are no laws or industry regulations that require firms to disclose their engagement in enterprise risk management or their risk governance practices. To overcome this challenge, we hand-collect all risk management data from financial reports available in the SEC's Edgar database. These reports include 10-K statements, proxy statements, and annual reports. For the purpose of this study, more than 1,000 annual reports and proxy statements have been analyzed to collect the required data.

The daily stock price data for all firms in our sample including the firms in the control group and the S\&P 500 index are collected from the Center for Research in 
Security Prices (CRSP). In addition, we collect data for the put option implied volatility (used in the calculation of our downside risk measure) from the OptionMetrics database.

\section{Dependent Variable}

The dependent variable in our regressions is a dummy variable that captures whether or not a financial institution is the target of a class action lawsuit. We assign a value of one to all firms that have been sued during our sample period $(S U E D=1)$ and a value of zero to their matched peer firms $(S U E D=0)$.

\section{Risk Management Variables}

To test our hypothesis, we define a series of variables that will help us measure the CRO's power and independence in a financial institution's corporate structure. To accomplish this, we look at the presence of a designated CRO, his power and degree of independence, and the responsibilities that are designated to him within the firm's organizational hierarchy. In addition, we capture whether the firm has a designated board committee that is responsible for overseeing the firm's risk management, assessment, and mitigation and its characteristics as another venue of enforcing and implementing the risk management and control functions in a firm.

Caliendo and Kopeinig (2008) point out that only factors that are not affected by the treatment should be considered when choosing variables for inclusion in logit regression models. In order to guarantee that our chosen variables are not influenced by their participation in the treatment group, we measure them one year before the participation year, i.e., the year of litigation. 
Keeping the above-mentioned point in mind, we collect CRO-related data for each of the three years prior to the year in which the litigation took place. There are two reasons for choosing a three-year pre-litigation window for our data collection. First, we believe that three years provides a period that is long enough for senior risk officers to implement their desired strategies or correct inaccuracies as they see fit. Second, the extensive work effort that is required when manually collecting and validating data deterred us from considering longer periods. The following is a thorough description of the risk management variables employed in our study:

CRO c-suite: this dummy variable takes on a value of one if the financial institution's CRO is an executive of the firm $($ SUITE $=1)$ and zero otherwise $($ SUITE $=$ $0)$;

CRO compensation: when performing their principal component analysis, Ellul and Yerramilli (2012) notice that the ratio of the CRO's compensation to the CEO's compensation is the most significant variable in their risk management index. This variable acts as a proxy for the CRO's power and influence in the governance structure of the firm. To complement our hand-collected compensation data, we use the Compustat ExecuComp database. Unfortunately, because public firms are only legally obligated to disclose the compensation packages of their top five executives, we were not able to find information about the CRO's compensation package for all firms in our sample. To circumvent this problem we take an approach similar to the one proposed by Ellul and Yerramilli (2012). Specifically, we subtract a percentage point from the ratio of the compensation package of the fifth highest paid executive to the CEO's compensation and consider this as our CRO compensation proxy. Contrary to Ellul and Yerramilli (2012), 
we do not define an imaginary CRO compensation package for firms that do not have a CRO position in their corporate structure. This variable is defined as the ratio of the CRO's total compensation package to the CEO's total compensation package (COMP);

CRO experience: this dummy variable takes on a value of one if the financial institution's CRO has risk-related experience $(X P=1)$ and zero otherwise $(X P=0)$;

$C R O$ reporting: this dummy variable takes on a value of one if the $\mathrm{CRO}$ has a direct reporting line to the board of directors $(R E P=1)$ and zero otherwise $(R E P=0)$;

CRO tenure: we define CRO tenure variable as the number of years since the CRO was in his/her position (TEN);

CRO top5: this dummy variable takes on a value of one if the financial institution's CRO is one of the top five paid executives of the firm $($ TOP5 $=1)$ and zero otherwise $($ TOP5 $=0)$;

Risk committee: this dummy variable takes on a value of one if there is a designated committee among the firm's board committees that is directly responsible for managing and monitoring the risk functions in the firm $(C O M M I T T E E=1)$ and zero otherwise $(C O M M I T T E E=0)$. Contrary to Ellul and Yerramilli (2012) we distinguish between committees that are exclusively responsible for risk management and committees that have risk management responsibilities combined with their main functions (e.g., an audit committee). By incorporating such restrictions, we follow the recommendation of Mongiardino and Plath (2009) who argue that overburdening the audit committee will push risk functions into the shadows and might thus hamper the desired outcome of these functions; 
Risk committee experience: this dummy variable takes on a value of one if at least one of the directors of the risk committee has risk management related experience $\left(C O M M I T T E E_{-} X P=1\right)$ and zero otherwise $\left(C O M M I T T E E \_X P=0\right)$. Contrary to Ellul and Yerramilli (2012), we are only interested in the risk management related experience of board members and not in broader aspects such as "banking experience" or "financial experience";

Risk committee meetings: the risk committee meetings variable is defined as the number of risk committee meetings throughout the year (COMMITTEE_MEET).

As previously mentioned, we employ principal component analysis to construct a risk management factor. Specifically, we construct two different versions of this factor. First, we only calculate the risk management factor based on the data for one year prior to the year of litigation $\left(R M_{-} 1 Y\right)$. Accordingly, only the accounting and financial variables of that year will be included in our models. Second, we consider the three-year average of the risk management factor $\left(R M \_3 Y\right)$ as our variable of interest. We calculate the risk management factor for each year and then calculate the three-year average. Accordingly, we include the three-year averages of all accounting and financial variables in the models with the three-year average of the risk management factor.

\section{Control Variables}

We control for various characteristics of financial institutions that may potentially affect the dependent variable in our proposed regression analyses. The extant literature on litigation risk has identified several variables that affect the probability of a firm being sued. These characteristics include: the firm's profitability, its enterprise-wide risk 
characteristics, share turnover, past volatility, stock returns, the total number of shares held by the CEO, the litigation history of the firm, and the percentage of CEO compensation from bonuses. The following is an explanation of our control variables:

Accruals: we employ two definitions of accruals ratio $(A C C)$ in our study. The total accruals ratio ( $\left.A C C_{-} T T\right)$ is defined in as the ratio of income before extraordinary items minus operating cash flows minus cash flows from investment divided by total assets. We also consider operating accruals which is defined as the ratio of income before extraordinary items minus operating cash flows to total assets $\left(A C C \_O P\right)$. Peng and Röell (2008) employ the accruals ratio as a proxy for overstatement and manipulation in financial statements and report a significant positive impact of this variable on litigation probability;

Auditor: prior studies (e.g., Raman and Wilson (1994)) provide evidence that suggest that higher quality audit reports prepared by the big four accounting firms (in order of latest revenue figures: PricewaterhouseCoopers, Deloitte \& Touche, Ernst \& Young, and KPMG) may provide some form of guarantee for the accuracy of the firm's financial statements. On the other hand, because auditors of sued firms can be held liable alongside the firm itself, the deep pocket theory suggests that the presence of big multinational accounting firms may attract more litigation (Alexander (1991); DuCharme, Malatesta, and Sefcik (2004)). To test the validity of these prepositions, we use the auditor code in the Compustat dataset to identify the firm's auditor. If the auditor is one of the big four audit firms then we assign a value of one to the auditor dummy variable $(A U D)$, otherwise the auditor dummy is equal to zero. In our three-year average 
regressions we assign a value of one to the auditor dummy when the firm's auditor was one of the big four audit firms in all three years; otherwise the auditor dummy is zero;

CEO compensation from bonuses: the CEO compensation from bonuses variable $(B O N)$ is the ratio of the CEO's bonuses to the CEO's total compensation (defined as the sum of salary, bonuses, other annual compensation, restricted stock grants, and the value of options exercised). We also calculate another variation of the CEO's compensation from bonuses variable by dividing CEO bonuses by the CEO's total current compensation defined as the sum of salary and bonuses. Gande and Lewis (2009) argue that higher proportion of bonus compensation for the CEOs can provide enough incentives for them to have a better performance and, consequently, mitigate the litigation probability of the firm. Therefore, we expect a negative relation between the percentage of the CEO's compensation from bonuses and the firm's litigation likelihood;

Enterprise-wide risk characteristics: Ellul and Yerramilli (2012) show that firms that were better positioned in terms of their risk management experienced lower levels of enterprise-wide risks during the 2007-2008 crisis. By including these risk measures in our regressions we aim to explore whether the enterprise-wide risk characteristics of financial institutions affect litigation probability. Following Ellul and Yerramilli (2012) we use three different risk metrics to proxy for enterprise-wide risk (ENT): aggregate risk, tail risk, and downside risk. Aggregate risk $\left(E N T \_A G G\right)$ is the standard deviation of the financial institution's weekly return minus the S\&P 500's weekly return over the year. Tail risk is calculated in two different ways. Under the first method, tail risk $\left(E N T \_T A I L_{-} I\right)$ is defined as the negative of the financial institution's average return during the 5\% of days on which the S\&P 500 recorded its lowest returns. Under the 
second method, tail risk (ENT_TAIL_II) is calculated as the negative of the average return of each firm in our sample during the $5 \%$ of days on which the stock itself recorded its worst performance over the year. Ellul and Yerramilli (2012) implement this second definition in order to make sure that their risk measure is not solely capturing the return of the S\&P 500 index. Lastly, downside risk $\left(E N T \_D O W N\right)$ is the average implied volatility of the put options traded on the stocks of each firm in our sample. The data for the put option implied volatility is collected from the OptionMetrics database;

Fixed effects: in all our models we include year fixed effects and industry fixed effects $(F E)$ as dummies to control for the effects these variables may have in our models. For brevity, the regression coefficients for these variables are not reported in our tables.

Institutional ownership: the institutional ownership variable (INST) is the ratio of the number of shares held by institutional shareholders at the end of the year to the total number of shares outstanding. We retrieve the institutional holdings data from the Thomson Financial database which provides information on the holdings of all institutions that are legally obligated to file form $13 \mathrm{~F}$ with the SEC and have more than $\$ 100$ million assets under management. These institutions include bank trusts, insurance companies, investment companies, investment advisors, pension funds, and endowments. Similar to Kim and Skinner (2012), we expect this variable to have a positive effect on a firm's litigation risk;

Leverage: we employ two different definitions of leverage variable (LEV) in our models, namely book leverage $\left(L E V_{-} B\right)$ and market leverage $\left(L E V_{-} M\right)$. Book leverage is defined as total assets minus the book value of equity divided by total assets while market 
leverage is the ratio of total assets minus the book value of equity to total assets minus the book value of equity plus the market value of equity. Peng and Röell (2008) argue that higher debt may be an indication of a firm's poor performance of firms which could lead to dissatisfaction among the firm's shareholders and, ultimately, shareholder litigation. Therefore, we expect the leverage to have a significant positive effect on the litigation probability;

Litigation history: following the work of Gande and Lewis (2009) who show that firms that have a history of litigation are more likely to be sued in the future, we introduce this dummy variable (LIT) in our models to evaluate whether past litigous behavior has any significant effect on the likelihood of future litigation. Therefore, we assign a value of one to this variable for firms that have been sued in any time during the past three years prior to the litigation year and zero otherwise. As suggestd by Ertugrul and Hegde (2009) and Gande and Lewis (2009) we expect this variable to have a positive effect on litigation probability;

Profitability: we employ three different measure of profitability (PROF) in our study. Return on assets $(R O A)$ is defined as net income before taxes plus interest expenses divided by total assets. To ensure the robustness of our results, we also consider the return on equity $(R O E)$ and the return on invested capital (ROIC) as alternative measures of a firm's profitability. ROE is defined as net income before taxes plus interest expenses divided by the book value of equity while ROIC is defined as net income divided by the previous year's total capital, i.e., the sum of the firm's common equity, preferred stock, and short- and long-term debt. Similar to Gande and Lewis (2009) we expect profitable firms to be less likely to be sued; 
Profitability variation: we use the three-year standard deviation of each of the profitability measures as a proxy for the variation in a firm's profitability (PROF_SD). Specifically, we calculate three variables, namely the variation in the return on equity ( $\left.R O E \_S D\right)$, the variation in the return on assets $\left(R O A \_S D\right)$, and the variation in the return on invested capital (ROIC_SD). Lowry and Shu (2002) compare the characteristics of sued and non-sued firms and notice that the standard deviation of daily stock returns is significantly higher for sued firms. Thus, we expect a positive relation between these three variables and a firm's litigation risk;

Share turnover: we define share turnover (TURN) as the number of shares traded divided by the number of shares outstanding, based on data for one year prior to the litigation year. Gande and Lewis (2009) argue that an increase in share turnover increases the likelihood that share purchases may be driven by inaccurate information which, in turn, may increase a firm's litigation risk;

Shares held by the CEO: we calculate this variable (SHARE) by dividing the total number of shares held by the CEO of the company by the total number of shares outstanding. As the findings of Gande and Lewis (2009) suggest, the alignment of management and shareholders incentives can have a negative effect on the lawsuit probability of a firm. Therefore, we expect to observe a negative relation between this variable and litigation likelihood in our models;

Stock return: we calculate a company's stock return (RET) as the percentage stock return during the year prior to the litigation year. All stock prices are retrieved from 
CRSP. Gande and Lewis (2009) find that prior stock returns have a significant negative effect on the shareholder litigation probability;

Stock return variation: to calculate stock return variation $\left(R E T \_S D\right)$, we use the annual standard deviation of a firm's daily stock returns during the year prior to the litigation year. Gande and Lewis (2009) use the stock return variation as a proxy for purchases driven by inaccurate information and show that higher levels of this variable increase the firm's litigation likelihood.

Table 3 provides a general overview of the dependent, independent, and control variables we employ in this study and provides descriptions, data sources, literature sources, and predicted signs for each variable. Table 4 provides the same information for the risk management variables that we use in the construction of our risk management factor.

The following section presents different regression models that we will be using to examine the effect of our risk management factor on a firm's litigation probability. Equation (1) represents the primary model that we estimate in this study:

$$
\begin{aligned}
S U E D_{i, t}=\alpha+ & \beta_{1} R M_{-} 1 Y_{i, t-1}+\beta_{2} P_{R O F_{i, t-1}}+\beta_{3} P R O F_{-} S D_{i, t-1}+\beta_{4} L E V_{i, t-1} \\
& +\beta_{5} T_{U R N_{i, t-1}}+\beta_{7} R E T_{i, t-1}+\beta_{8} R E T_{-} S D_{i, t-1}+\beta_{9} A U D_{i, t-1} \\
& +\beta_{10} L I T_{i, t-1}+F E_{i, t-1}+\varepsilon_{i, t-1}
\end{aligned}
$$

This model does not exclude any of our observations. Due to data unavailability for some firms, including either one of our two accrual ratios in this model causes a reduction in the number of observations. Therefore, as a variation to our primary model, Equation (2) includes the accruals ratio as an additional control variable: 


$$
\begin{aligned}
S U E D_{i, t}=\alpha+ & \beta_{1} R M_{-} 1 Y_{i, t-1}+\beta_{2} P_{R O F_{i, t-1}}+\beta_{3} P R O F_{-} S D_{i, t-1}+\beta_{4} L E V_{i, t-1} \\
& +\beta_{5} T U R N_{i, t-1}+\beta_{7} R E T_{i, t-1}+\beta_{8} R E T_{-} S D_{i, t-1}+\beta_{9} A U D_{i, t-1} \\
& +\beta_{10} L I T_{i, t-1}+\beta_{11} A C C_{i, t-1}+F E_{i, t-1}+\varepsilon_{i, t-1}
\end{aligned}
$$

Since the results of our analysis do not change by including the accruals ratio we consider Equation (1) as the primary model in the rest of the study.

To ensure the robustness of our results, we also consider a model in which we add two additional variables to our base model, namely CEO compensation from bonuses and shares held by the CEO. There are two reasons why we do not include these variables in our primary model. First, we believe that these variables are partially represented by the CRO compensation variable. Second, because the information for the number of shares held by the CEO is not available for all the firms in our sample and control group, the inclusion of this variable will reduce our sample size. Equation (3) presents the model with these two measures as independent variables:

$$
\begin{aligned}
\text {SUED }_{i, t}=\alpha+ & \beta_{1} R M_{-} 1 Y_{i, t-1}+\beta_{2} \text { PROF }_{i, t-1}+\beta_{3} P R O F_{-} S D_{i, t-1}+\beta_{4} L E V_{i, t-1} \\
& +\beta_{5} T_{U R N_{i, t-1}}+\beta_{7} R E T_{i, t-1}+\beta_{8} R E T_{-} S D_{i, t-1}+\beta_{9} A U D_{i, t-1} \\
& +\beta_{10} L I T_{i, t-1}+\beta_{11} S H A R E_{i, t-1}+\beta_{12} \text { BON }_{i, t-1}+F E_{i, t-1}+\varepsilon_{i, t-1}
\end{aligned}
$$

In another sensitivity test, we add the enterprise wide risk characteristics to our base model. As noted earlier, these variables are: aggregate risk, tail risk, and downside risk. The three resultant models are presented in one general form in Equation (4): 


$$
\begin{aligned}
S U E D_{i, t}=\alpha+ & \beta_{1} R M_{-} 1 Y_{i, t-1}+\beta_{2} P R O F_{i, t-1}+\beta_{3} P R O F_{-} S D_{i, t-1}+\beta_{4} L E V_{i, t-1} \\
& +\beta_{5} T_{U R N_{i, t-1}}+\beta_{7} R E T_{i, t-1}+\beta_{8} R E T_{-} S D_{i, t-1}+\beta_{9} A U D_{i, t-1} \\
& +\beta_{10} L I T_{i, t-1}+\beta_{11} E N T_{i, t-1}+F E_{i, t-1}+\varepsilon_{i, t-1}
\end{aligned}
$$

Because we employ three proxies for enterprise-wide risk, we will estimate multiple versions of Model 4. Model 4.a employs aggregate risk as one of the independent variables, model 4.b and model 4.c each use one of the two variations of tail risk while downside risk is included in model 4.d. Because downside risk uses the implied volatility of the put options written on the company's stock as a risk measure and because not all firms have put options on their stock, the inclusion of this variable eliminates 60 observations from our data set.

In a final robustness test, we include institutional ownership as one of the control variables in our analysis. Because we are unable to find institutional holdings for all firms in our sample and in some cases we had to ignore the observation in our sample because the percentage of its institutional holdings were more than $100 \%$ of the total number of shares outstanding due to double counting, the number of observations for this model is slightly less than the number of observations in our base model. Equation (5) presents our model with institutional ownership as a control variable:

$$
\begin{aligned}
\text {SUED }_{i, t}=\alpha+ & \beta_{1} R M_{-} 1 Y_{i, t-1}+\beta_{2} \text { PROF }_{i, t-1}+\beta_{3} P R O F_{-} S D_{i, t-1}+\beta_{4} L E V_{i, t-1} \\
& +\beta_{5} T_{U R N_{i, t-1}}+\beta_{7} R E T_{i, t-1}+\beta_{8} R E T_{-} S D_{i, t-1}+\beta_{9} A U D_{i, t-1} \\
& +\beta_{10} L I T_{i, t-1}+\beta_{11} I N S T_{i, t-1}+F E_{i, t-1}+\varepsilon_{i, t-1}
\end{aligned}
$$


In the next section, we provide summary statistics for all variables in our regression models and present the results for a series of univariate tests between sued and non-sued firms.

\section{SUMMARY STATISTICS}

We present summary statistics for the components of our risk management factor and for all control variables in Panels A and B of Table 5, respectively. The figures in Panel A provide some interesting insights into the risk management characteristics of the financial institutions in our sample.

To provide some initial insight into the differences between the risk management characteristics of sued and non-sued firms, we perform a series of univariate comparison tests between our two subsamples. The results of our t-tests show that there are significant differences in the variables $\mathrm{CRO}$ c-suite, CRO compensation, $\mathrm{CRO}$ tenure, CRO top5, and risk committee experience between sued and non-sued financial institutions. The chief risk officer holds an executive position in $54.29 \%$ of all non-sued firms compared to $28.72 \%$ for all sued firms. The CRO's total compensation package is on average $63.60 \%$ of the CEO's total compensation package in non-sued firms but only $46.97 \%$ in sued firms. This difference indicates that CROs have more power and influence in non-sued financial institutions. An alternate specification of this variable, i.e., a CRO compensation dummy, provides the same conclusion. The CRO tenure variable and its dummy counterpart indicate that CROs in non-sued firms held their 
positions longer the CROs in sued firms. In our sample, we observe that the CRO is among the top five executives in $16.33 \%$ of our non-sued firms but in only $7.09 \%$ of sued firms.

Even though there is no significant difference in the proportion of firms that have an independent risk committee between our sued and non-sued sub-sample, there is a statistically significant difference between the proportion of firms that have at least one committee member with risk management related experience. More specifically, 20.41\% of the observations in our non-sued sample had at least one committee member with such experience while the proportion is $13.12 \%$ in our sued sample. This difference implies that although the presence of an independent risk committee is not different in our two samples but the experience of their members is significantly different.

Most importantly, there is a significant difference between the mean and median of the risk management factor in our sued and non-sued firms' samples. Both t-test and Wilcoxon test show that the differences are significant at one percent level providing evidence that non-sued financial firms in our sample have higher levels of risk management factor.

The figures in Table 5 Panel B illustrate some significant differences between the firm characteristics of sued and non-sued financial institutions in our sample. The results of our t-tests show that there are significant differences in the variables auditor, downside risk, institutional ownership, litigation history, all profitability measures and the variation in the profitability measures, and share turnover. The results of Wilcoxon test, while confirming these significant differences, highlight the significant differences between 
leverage, share ownership of the CEO, stock return, and stock return variation. Overall, the results suggest that on average a higher proportion of the sued firm in our sample were audited by one of the big four audit firms and were sued in the past. Additionally, an average sued firm of our sample has higher institutional shareholder ratio, lower performance and higher performance variability, and higher share turnover.

In Table 6 we provide the pair-wise Pearson correlations among our independent variable, risk management factor, and control variables from our base model. As expected, firms with higher levels of risk management factor enjoy lower levels of lawsuit probability while share turnover, the presence of one of big four audit companies, and having a litigation history positively and significantly affect the litigation probability.

The negative correlation between the risk management factor and both the stock return and profitability implies that implementing more rigid risk management and control measures could lower the short-term performance of the firm. The positive and significant relation between the auditor variable and our risk management factor indicates that firms that are audited by one of the big four audit firms have better risk management practices in place. There is also a significant positive correlation between share turnover and the risk management factor.

Since the results presented in Table 6 are simply pair-wise correlations without including any control variables, we cannot make any robust conclusions regarding the validity of our assumptions. Therefore, in the following section, we turn our attention to the multivariate regressions that enable us to control for various firms characteristics in our sample. 


\section{MULTIVARIATE REGRESSIONS}

The results of our multivariate regressions are reported in Table 7 for the prioryear risk management factor and in Table 8 for the three-year average risk management factor.

The regression results are firmly in line with our assumptions. The risk management variable is significantly negative at the one percent level based on either the one year risk management index or its three-year average. The sign suggests that firms that have better overall risk management practices as part of their corporate structure face a significantly lower probability of being sued. The results are robust when we include different control variables or employ different definitions of these control variables.

The signs for our control variables are largely in line with what has been found in the prior literature. Litigation history is positive and significant in all of our models suggesting that firms that faced prior litigation are more likely to be the target of another lawsuit in the future. Higher profitability and market performance lowers a firm's litigation risk while higher share turnover increases a firm's litigation risk. The coefficients for our profitability and stock return variation variables are insignificant and inconsistent in their sign.

Contrary to our expectation, firms with higher book and market leverage have a lower probability of being sued. This observation, although not significant, is consistent across all models. Similar to the findings of Gande and Lewis (2009), we observe a negative relation between variables that proxy for the alignment of the CEO's and the shareholders' incentives. Of these two proxies, only the CEO's bonus compensation is 
significant one at the ten percent level. Except for the aggregate risk variable, the signs of our enterprise-wide risk measures are in line with our expectations. The positive sign of both definitions of the tail risk measure, which Ellul and Yerramilli (2012) use as their main measure of enterprise-wide risk, implies that sued financial institutions experience higher levels of risk one year prior to the litigation.

The coefficient for our auditor variable is insignificant in all settings but the positive sign in most cases provides some potential support of the deep pocket theory indicating that firms that use the services of these big international audit companies appear to face higher litigation risk because of the presence of a wealthier audit firm. The institutional ownership variable is positive and significant which is in line with the findings of Kim and Skinner (2012). This finding suggests that institutional monitoring may not be such an effective tool in lowering the litigation risk of financial institutions.

In summary, after controlling for different firm characteristics and variables that have been shown in the literature to have a significant effect on the probability of litigation, our analysis provides robust evidence of a significant negative effect of the risk management factor on the probability of a financial institution being sued in a securities class action. This finding underlines the importance of powerful risk management. Financial institutions that are empowered by better risk management practices (such as more powerful CROs and risk management committees) are less likely to become the target of shareholders class action lawsuits. 


\section{PREDICTIVE ABILITY}

In the last two sections, we demonstrated that our proposed risk management factor significantly and negatively affects the litigation probability of a firm. In order to test the predictive ability of our model, we run out-of-sample tests to evaluate the accuracy of our models in separating sued from non-sued firms. We are specifically interested in comparing the results of our model with a similar model that excludes the risk management factor.

The tests performed here only partially show the power of the models and are not true tests of the predictive ability of our models. Similar to Powell (2004) we believe that the power of the model can only be tested in its ability to clearly flag sued firms in a complete population of firms. Because we are unable to calculate the risk management factor for all or even a representative sub-sample of financial institutions, we cannot perform such a test. As such, our tests only partially explore the predictive ability of our models. Yet, our tests results provide good preliminary indications that our model has better predictive ability compared to prior models that have previously been proposed in the literature. In addition to providing a better tool to assess the litigation probability of a firm, our model can be used to analyze the effectiveness of risk management measures in reducing the exposure of financial institutions to class action lawsuits. Therefore, they could be implemented as some form of risk measurement and management in financial institutions.

Our test is performed in the following fashion: we take the last three years of our sample and perform three out-of-sample tests. For example, for the year 2011, we include 
all observations before this year in our estimation model and use the observations of the year 2011 as our verification period. Then, we compare the performance of our model to a similar model without the risk management factor. We employ the same procedure for the years 2009 and 2010. We define two measures of prediction accuracy. Accuracy $I$ is the ratio of the total number of correct predictions (either sued or not sued) in the verification year to the total number of observations in the verification year while Accuracy II is the number of correct predictions of sued firms in the verification year to the total number of sued firms in the verification year.

Prior literature in this area (e.g., Palepu (1986) and Powell (2004)) has employed different methodologies for determining the cut-off point for each firm's classification. Given that we employ a one-to-one matching procedure when constructing our sample, we can entirely avoid these discussions and assume a 50\% probability as our cut-off point because the number of treated and non-treated firms in our data set is equal (see also Powell, 2004).

Table 9 presents the variable coefficients for each of our three prediction tests together with our two accuracy measures for each model's prediction in the subsequent year. Both accuracy measures show improvements when we add the risk management factor to the model. The results suggest that the addition of the risk management factor improves the predictive ability of the model in identifying firms that are most likely to be sued in the coming year. Although these results are promising we cannot draw any definite conclusion about the predictive power of our model without analyzing the performance of the model for a complete sample. 


\section{ADDITIONAL ROBUSTNESS TESTS}

In this section, we provide details of the additional robustness tests that have been employed to ensure the credibility of our results. Because the conclusions are not sensitive, either qualitatively or quantitatively, to any of these changes and for brevity of the presentation of the results, we do not report the results of these tests in detail.

First, we explore the sensitivity of our conclusions to the method chosen for factor analysis. We employ two other methods to construct our risk management factor, namely Principal Factors Analysis and Maximum Likelihood Factor Analysis. PROC FACTOR command in SAS is used for the construction of these factors. The results are both qualitatively and quantitatively similar to the results from the principal component analysis. This finding shows that our conclusions are not driven by the method of factor construction.

Second, we consider dividing our sample into two sub-samples of firms that are sued due to fraudulent behavior and firms that are sued because of providing the market with material misinformation. The results of our base model regression on these two subsamples are qualitatively and quantitatively similar to the results from full sample. This finding indicates that our conclusions are not driven by the type of litigation in our sample.

Third, we construct alternative risk management factors in order to ensure the insensitivity of our conclusions to the underlying variables of the risk management factor.

First, we construct a risk management factor without including CRO tenure variable $(T E N)$ because we are concerned that the inclusion of this variable may simply capture a 
time trend in our models and biases our conclusions. Second, we change the definition of three of our underlying risk management variables and transform them into dummy variables. These three new variables are CRO compensation dummy which takes on a value of one if the ratio of the CRO's to the CEO's total compensation package is above the average of all financial institutions in our sample $(C O M P=1)$ and zero otherwise $(C O M P=0)$, risk committee meetings dummy which takes on the value of one if the risk committee meeting frequency is equal to or more than the average number of risk committee meetings across all financial institutions in our sample (COMMITTEE_MEET $=1)$ and zero otherwise $\left(C O M M I T T E E \_M E E T=0\right)$, and CRO tenure dummy which takes on a value of one if the financial institution introduced its first CRO earlier than the average of all financial institutions in our sample $(T E N=1)$ and zero otherwise $(T E N=$ $0)$. The results for these alternative definitions of our risk management factor are similar both in terms of sign and significance which ensures us of the robustness of our conclusions based on the base definition of our risk management factor.

\section{SUMMARY AND CONCLUSIONS}

In recent years, a variety of legislative and regulatory bodies have pressured financial firms to improve their risk governance structures to better weather any potential future crises. Assuming that CROs are given sufficient power to influence the corporate governance of financial institutions, can they provide these firms with the promised benefits? In this study, we aim to answer this question by comparing the risk management in sued versus non-sued financial institutions. To perform this comparison, 
we manually collect risk management characteristics of 85 sued and 85 non-sued financial firms that have banking-related operations as their main line of business and, using principal component analysis, construct a single risk management factor which captures most of the variations in these characteristics. By including this new variable in models proposed in the previous literature, we provide evidence of a significant negative impact of the prior year and three-year average risk management factor on litigation probability. To further reinforce our proposition, we perform a series of out-of-sample tests and show that the addition of this risk management factor to previously established models improves the overall accuracy of these models in identifying companies that are most susceptible to class action lawsuits. Overall, our results suggest that the litigation exposure of financial institutions can be reduced by putting stronger and more independent risk management functions in place.

\section{FUTURE RESEARCH}

Aside from expansion possibilities such as performing this study in industries other than the financial sector and focusing on a different sample of lawsuits (such as IPO cases) we propose the following extensions to our study:

First, it would be interesting to look at the stockholders' reaction to litigation announcements. Do investors penalize firms with better risk management structures in the same fashion as their peers with poor risk governance? Performing this study could 
shed some light on the ex-post effects of establishing strong risk management practices in financial institutions.

Throughout this study we did not account for variations in lawsuit characteristics or their outcomes. As a second possible extension to this study, it may thus be interesting to analyze subsets of our sample based on lawsuits' characteristics such as the presence of an accountant as a co-defendant, an institutional lead plaintiff, or lawsuit outcomes (e.g., settlements vs. dismissals). This would shed some light on the ex-post effects of risk management checks and balances. 


\section{REFERENCES}

Adams, R., \& Mehran, H. (2002). Board Structure and Banking Firm Performance. Federal Reserve Bank of New York, Unpublished Paper.

Adams, R., \& Mehran, H. (2003). Is Corporate Governance Different for Bank Holding Companies? Federal Reserve Bank of New York Economic Policy Review, 9(1), 123-142.

Aebi, V., Sabato, G., \& Schmid, M. (2011). Risk Management, Corporate Governance, and Bank Performance in the Financial Crisis. Journal of Banking \& Finance, 36(12), 3213-3226.

Alexander, J. (1991). Do the Merits Matter? A Study of Settlements in Securities Class Actions. Stanford Law Review, 43(3), 498-598.

Atanasov, V., Ivanov, V., \& Litvak, K. (2012). Does Reputation Limit Opportunistic Behavior in the VC Industry? Evidence from Litigation Against VCs. The Journal of Finance, 67(6), 2215-2246.

Bank for International Settlements. (2009). 79th Annual Report. Bank for International Settlements.

Basel Committee on Banking Supervision. (2012, September). Core Principles for Effective Banking Supervision. Retrieved October 23, 2012, from http://www.bis.org/publ/bcbs230.htm

Becker, S., \& Ichino, A. (2002). Estimation of Average Treatment Effects Based on Propensity Scores. The Stata Journal, 2(4), 358-377.

Behr, A., \& Heid, F. (2011). The Success of Bank Mergers Revisited. An Assessment Based on a Matching Strategy. Journal of Empirical Finance, 18(1), 117-135.

Caliendo, M., \& Kopeinig, S. (2008). Some Practical Guidance for the Implementation of Propensity Score Matching. Journal of Economic Surveys, 22(1), 31-72.

Callahan, W., Millar, J., \& Schulman, C. (2003). An Analysis of the Effect of Management Participation in Director Selection on the Long-term Performance of the Firm. Journal of Corporate Finance, 9(2), 169-181.

Chintrakarn, P. (2008). Estimating the Euro Effects on Trade with Propensity Score Matching. Review of International Economics, 16(1), 186-198. 
Dehejia, R. H., \& Wahba, S. (1999). Causal Effects in Nonexperimental Studies: Reevaluating the Evaluation of Training Programs. Journal of the American Statistical Association, 94(448), 1053-1062.

DuCharme, L., Malatesta, P., \& Sefcik, S. (2004). Earnings Management, Stock Issues, and Shareholder Lawsuits. Journal of Financial Economics, 71(1), 27-49.

Ellul, A., \& Yerramilli, V. (2012). Stronger Risk Controls, Lower Risk: Evidence from U.S. Bank Holding Companies. Journal of Finance, forthcoming.

Ertugrul, M., \& Hegde, S. (2009). Corporate Governance Ratings and Firm Performance. Financial Management, 38(1), 139-160.

Faulkender, M., \& Yang, J. (2010). Inside the Black Box: The Role and Composition of Compensation Peer Groups. Journal of Financial Economics, 96(2), 257-270.

Field, L., Lowry, M., \& Shu, S. (2005). Does Disclosure Deter or Trigger Litigation? Journal of Accounting and Economics, 39(3), 487-507.

Gande, A., \& Lewis, C. (2009). Shareholder Initiated Class Action Lawsuits: Shareholder Wealth Effects and Industry Spillovers. Journal of Financial and Quantitative Analysis, 44(4), 823-850.

Green, P., \& Jennings-Mares, J. (2008). IIF's Final Report on Market Best Practices for Financial Institutions and Financial Products. Banking \& Financial Services Policy Report, 27(9), 1-5.

Havrylchyk, O., \& Jurzyk, E. (2011). Inherited or Earned? Performance of Foreign Banks in Central and Eastern Europe. Journal of Banking \& Finance, 35(5), 1291-1302.

Hoyt, R., \& Liebenberg, A. (2011). The Value of Enterprise Risk Management. Journal of Risk and Insurance, 78(4), 795-822.

Kim, I., \& Skinner, D. (2012). Measuring Securities Litigation Risk. Journal of Accounting and Economics, 53(1-2), 290-310.

Kirkpatrick, G. (2009). The Corporate Governance Lessons from the Financial Crisis. OECD Journal: Financial Market Trends, 2009(1), 61-87.

LaLonde, R. (1986). Evaluating the Econometric Evaluations of Training Programs with Experimental Data. The American Economic Review, 76(4), 604-620.

Liebenberg, A., \& Hoyt, R. (2003). The Determinants of Enterprise Risk Management: Evidence from the Appointment of Chief Risk Officers. Risk Management and Insurance Review, 6(1), 37-52. 
Lowry, M., \& Shu, S. (2002). Litigation Risk and IPO Underpricing. Journal of Financial Economics, 65(3), 309-335.

Mikes, A. (2010). Becoming the Lamp Bearer: The Emerging Roles of the Chief Risk Officer. In J. Fraser, \& B. Simkins, Enterprise Risk Management: Today's Leading Research and Best Practices for Tomorrow's Executives (pp. 71-87). New York, NY: Wiley.

Mongiardino, A., \& Plath, C. (2009). Risk Governance at Large Banks: Have Any Lessons Been Learned? Journal of Risk Management in Financial Institutions, 3(2), 116-123.

Palepu, K. (1986). Predicting Takeover Targets. Journal of Accounting and Economics, $8(1), 3-35$.

Peng, L., \& Röell, A. (2008). Executive Pay and Shareholder Litigation. Review of Finance, 12(1), 141-184.

Pezier, J. (2010). Market Risk Management. In C. Alexander, \& E. Sheedy, The Professional Risk Managers' Handbook - Volume III: Risk Management Practices (pp. 46-47).

Powell, R. (2004). Takeover Prediction Models and Portfolio Strategies: A Multinomial Approach. Multinational Finance Journal, 8(1), 35-72.

Powell, R., \& Yawson, A. (2007). Are Corporate Restructuring Events Driven by Common Factors? Implications for Takeover Prediction. Journal of Business Finance \& Accounting, 34(7-8), 1169-1192.

Raman, K., \& Wilson, E. (1994). Governmental Audit Procurement Practices and Seasoned Bond Prices. The Accounting Review, 69(4), 517-538.

Romano, R. (1991). The Shareholder Suit: Litigation without Foundation? Journal of Law, Economics, \& Organization, 7(1), 55-87.

Rosenbaum, P., \& Rubin, D. (1984). Reducing Bias in Observational Studies Using Subclassification on the Propensity Score. Journal of the American Statistical Association, 79(387), 516-524.

Scott, A. (2011, October 21). Number Crunching at the Apocalypse. New York Times, p. C1.

Senior Supervisors' Group. (2009). Risk Management Lessons from the Global Banking Crisis of 2008. Senior Supervisors' Group. 
Tetlock, P. (2007). Giving Content to Investor Sentiment: The Role of Media in the Stock Market. The Journal of Finance, 62(3), 1139-1168.

Valukas, A. (2010). Report of the Examiner in the Chapter 11 Proceedings of Lehman Brothers Holdings Inc. Retrieved October 23, 2012, from jenner.com/lehman 


\section{Table 1: Litigation trend}

This table provides information on the number of litigation cases for all financial firms (firms with one-digit SIC codes of 6) and financial firms included in our final sample which are firms with banking-related operations as their main line of business (firms with four-digit SIC codes of 6021, 6022, 6029, 6035, and 6036) between 1996 and 2011. In the last three rows, we report information on the total number of litigation cases as well as yearly means and medians.

\begin{tabular}{c|c|c} 
Year & Filings for All Financial Firms & Filings for Financial Firms in the Final Sample \\
\hline \hline 1996 & 7 & 0 \\
1997 & 15 & 0 \\
1998 & 14 & 0 \\
1999 & 18 & 3 \\
2000 & 25 & 1 \\
2001 & 13 & 2 \\
2002 & 31 & 5 \\
2003 & 43 & 6 \\
2004 & 34 & 5 \\
2005 & 25 & 5 \\
2006 & 12 & 1 \\
2007 & 43 & 10 \\
2008 & 79 & 18 \\
2009 & 36 & 10 \\
2010 & 20 & 11 \\
2011 & 14 & 8 \\
\hline \hline Total & 429 & 85 \\
Average & 27 & 7 \\
Median & 23 & 5
\end{tabular}




\section{Table 2: Litigation breakdown by industry}

This table provides information on the yearly number of litigation cases for financial firms included in our final sample between 1999 and 2011. Our sample includes 85 firms with SIC codes of 6021 (national commercial banks), 6022 (state commercial banks), 6029 (commercial banks, NEC), 6035 (federally chartered savings institutions), and 6036 (not federally chartered savings institutions).

\begin{tabular}{c|c|c|c|c|c}
\multirow{2}{*}{ Year } & \multicolumn{6}{|c}{ SIC Code } \\
\cline { 2 - 6 } & $\mathbf{6 0 2 1}$ & $\mathbf{6 0 2 2}$ & $\mathbf{6 0 2 9}$ & $\mathbf{6 0 3 5}$ & $\mathbf{6 0 3 6}$ \\
\hline \hline 1999 & 3 & - & - & - & - \\
2000 & 1 & - & - & - & - \\
2001 & 1 & - & - & 1 & - \\
2002 & 3 & - & 1 & - & 1 \\
2003 & 2 & 3 & - & - & 1 \\
2004 & 3 & - & 1 & - & 1 \\
2005 & 3 & 2 & - & - & - \\
2006 & 1 & - & - & - & - \\
2007 & 2 & 4 & 1 & 3 & - \\
2008 & 12 & 6 & - & - & - \\
2009 & 6 & 4 & - & - & - \\
2010 & 2 & 8 & - & 1 & - \\
2011 & 4 & 4 & - & - & - \\
\hline \hline Total & 43 & 31 & 3 & 5 & 3
\end{tabular}




\section{Table 3: Risk management variables description}

This table provides descriptions and data sources of our risk management variables. These variables are used in our principal component analysis to construct the risk management factor.

\begin{tabular}{|c|c|c|}
\hline Variable Name & Variable Description & Data Source(s) \\
\hline $\mathrm{XP}$ & $\begin{array}{l}\text { This variable equals one if the firm's CRO has risk-related } \\
\text { experience and zero otherwise }\end{array}$ & Edgar \\
\hline TEN & $\begin{array}{l}\text { This variable equals the number of years since the CRO was in } \\
\text { this position }\end{array}$ & Edgar \\
\hline SUITE & $\begin{array}{c}\text { This variable equals one if the firm's CRO is an executive and } \\
\text { zero otherwise }\end{array}$ & Edgar \\
\hline TOP5 & $\begin{array}{l}\text { This variable equals one if the firm's CRO is one of the top five } \\
\text { paid executives of the firm and zero otherwise }\end{array}$ & Edgar \\
\hline COMP & $\begin{array}{l}\text { This variable equals the ratio of the CRO's total compensation } \\
\text { package to the CEO's total compensation package }\end{array}$ & $\begin{array}{c}\text { Edgar and } \\
\text { Compustat ExecuComp }\end{array}$ \\
\hline REP & $\begin{array}{l}\text { This variable equals one if the } \mathrm{CRO} \text { has a direct reporting line to } \\
\text { the board of directors and zero otherwise }\end{array}$ & Edgar \\
\hline COMMITTEE & $\begin{array}{c}\text { This variable equals one if there is a designated committee among } \\
\text { the board committees that is responsible for managing and } \\
\text { monitoring risk and zero otherwise }\end{array}$ & Edgar \\
\hline COMMITTEE_XP & $\begin{array}{l}\text { This variable equals one if at least one of the risk committee } \\
\text { directors has risk-related experience and zero otherwise }\end{array}$ & Edgar \\
\hline COMMITTEE_MEET & $\begin{array}{c}\text { This variable equals the number of risk committee meetings } \\
\text { throughout the year }\end{array}$ & Edgar \\
\hline
\end{tabular}




\section{Table 4: Dependent and independent variables description}

This table describes our dependent, independent, and control variables and provides data sources, literature sources, and predicted signs for each variable. Year $t$ denotes the litigation filing year.

\begin{tabular}{|c|c|c|c|c|}
\hline Variable Name & Variable Description & Data Source(s) & $\begin{array}{c}\text { Literature } \\
\text { Source(s) } \\
\end{array}$ & $\begin{array}{c}\text { Predicted } \\
\text { Sign } \\
\end{array}$ \\
\hline \multicolumn{5}{|c|}{ Dependent variable } \\
\hline SUED $_{\mathrm{t}}$ & $\begin{array}{l}\text { This variable equals one if the firm was the } \\
\text { defendant in a class action lawsuit in the 1999- } \\
2011 \text { period, and zero otherwise }\end{array}$ & $\begin{array}{l}\text { Stanford's Securities } \\
\text { Class Action } \\
\text { Clearinghouse (SCAC) }\end{array}$ & - & - \\
\hline \multicolumn{5}{|c|}{ Independent variables } \\
\hline $\mathrm{RM}_{\mathrm{t}-1}$ & $\begin{array}{l}\text { This factor is the single factor from a principal } \\
\text { component analysis with the highest eigenvalue } \\
\text { that can explain most of the variations in the } \\
\text { factors underlying risk management }\end{array}$ & $\begin{array}{l}\text { Edgar (10-K statements, } \\
\text { proxy statements, and } \\
\text { annual reports) and } \\
\text { Compustat ExecuComp }\end{array}$ & $\begin{array}{l}\text { Ellul and } \\
\text { Yerramilli } \\
(2012)\end{array}$ & - \\
\hline \multicolumn{5}{|c|}{ Control variables } \\
\hline $\mathrm{PROF}_{\mathrm{t}-1}$ & $\begin{array}{l}\text { Return on equity: net income before taxes plus } \\
\text { interest expenses divided by the book value of } \\
\text { equity } \\
\text { Return on assets: net income before taxes plus } \\
\text { interest expenses divided by total assets } \\
\text { Return on invested capital: net income divided } \\
\text { by the previous year's total capital which is } \\
\text { defined as the sum of common equity, preferred } \\
\text { stocks, short- and long-term debt }\end{array}$ & Compustat & $\begin{array}{l}\text { Gande and } \\
\text { Lewis (2009) }\end{array}$ & - \\
\hline
\end{tabular}


Table 4 - Continued

\begin{tabular}{|c|c|c|c|c|}
\hline Variable Name & Variable Description & Data Source(s) & $\begin{array}{c}\text { Literature } \\
\text { Source(s) } \\
\end{array}$ & $\begin{array}{c}\text { Predicted } \\
\text { Sign } \\
\end{array}$ \\
\hline PROF_SD & $\begin{array}{l}\text { Three-year standard deviation of annual } \\
\text { profitability }\end{array}$ & Compustat & $\begin{array}{l}\text { Lowry and Shu } \\
\text { (2002) }\end{array}$ & + \\
\hline $\mathrm{LEV}_{\mathrm{t}-1}$ & $\begin{array}{l}\text { Book leverage: total assets minus book value of } \\
\text { equity divided by total assets } \\
\text { Market leverage: ratio of total assets minus } \\
\text { book value of equity to total assets minus book } \\
\text { value of equity plus market value of equity }\end{array}$ & Compustat & $\begin{array}{l}\text { Peng and Röell } \\
\text { (2008) }\end{array}$ & + \\
\hline $\mathrm{ENT}_{\mathrm{t}-1}$ & $\begin{array}{l}\text { Aggregate risk: standard deviation of the firm's } \\
\text { weekly return minus S\&P 500's weekly return } \\
\text { Tail risk I: negative of firm's average return } \\
\text { during 5\% days that S\&P } 500 \text { recorded the } \\
\text { poorest returns } \\
\text { Tail risk II: negative of the average return of the } \\
\text { firm during the 5\% days that the stock itself } \\
\text { recorded its worst performance } \\
\text { Downside risk: average implied volatility of the } \\
\text { put options sold on the firm's stock }\end{array}$ & CRSP and OptionMetrics & - & + \\
\hline TURN $_{\mathrm{t}-1}$ & $\begin{array}{c}\text { Number of shares traded divided by total } \\
\text { number of shares outstanding calculated for one } \\
\text { year prior to the year of the litigation }\end{array}$ & Compustat & $\begin{array}{c}\text { Gande and } \\
\text { Lewis (2009) }\end{array}$ & + \\
\hline $\mathrm{ACC}_{\mathrm{t}-1}$ & $\begin{array}{l}\text { Total accruals: income before extraordinary } \\
\text { items minus operating cash flows minus cash } \\
\text { flows from investment to total assets } \\
\text { Operating accruals: ratio of income before } \\
\text { extraordinary items minus operating cash flows } \\
\text { to total assets }\end{array}$ & Compustat & $\begin{array}{l}\text { Peng and Röell } \\
\text { (2008) }\end{array}$ & + \\
\hline
\end{tabular}


Table 4 - Continued

\begin{tabular}{|c|c|c|c|c|}
\hline Variable Name & Variable Description & Data Source(s) & $\begin{array}{l}\text { Literature } \\
\text { Source(s) } \\
\end{array}$ & $\begin{array}{l}\text { Predicted } \\
\text { Sign } \\
\end{array}$ \\
\hline $\mathrm{RET}_{\mathrm{t}-1}$ & $\begin{array}{c}\text { Percentage stock return during the year prior to } \\
\text { the litigation year }\end{array}$ & CRSP & $\begin{array}{c}\text { Gande and } \\
\text { Lewis (2009) }\end{array}$ & - \\
\hline RET_SD ${ }_{t-1}$ & $\begin{array}{l}\text { Annualized standard deviation of daily stock } \\
\text { returns during the year prior to the litigation } \\
\text { year }\end{array}$ & CRSP & $\begin{array}{l}\text { Peng and Röell } \\
\text { (2008) }\end{array}$ & + \\
\hline $\mathrm{AUD}_{\mathrm{t}-1}$ & $\begin{array}{l}\text { This variable equals one if the firm's auditor is } \\
\text { one of the big four audit firms (i.e., } \\
\text { PricewaterhouseCoopers, Deloitte \& Touche, } \\
\text { Ernst \& Young, and KPMG) and zero otherwise }\end{array}$ & Compustat & $\begin{array}{c}\text { Raman and } \\
\text { Wilson (1994); } \\
\text { DuCharme et al. } \\
\text { (2004) }\end{array}$ & $+/-$ \\
\hline $\mathrm{BON}_{\mathrm{t}-1}$ & $\begin{array}{l}\text { Ratio of CEO bonuses to the CEO's total } \\
\text { compensation }\end{array}$ & $\begin{array}{l}\text { Edgar (10-K statements, } \\
\text { proxy statements, and } \\
\text { annual reports }) \text { and } \\
\text { Compustat ExecuComp }\end{array}$ & $\begin{array}{l}\text { Gande and } \\
\text { Lewis (2009) }\end{array}$ & - \\
\hline SHARE $_{\mathrm{t}-1}$ & $\begin{array}{c}\text { Total number of shares held by the CEO } \\
\text { divided by the total number of shares } \\
\text { outstanding }\end{array}$ & Compustat ExecuComp & $\begin{array}{l}\text { Gande and } \\
\text { Lewis (2009) }\end{array}$ & - \\
\hline $\operatorname{LIT}_{\mathrm{t}-3, \mathrm{t}-1}$ & $\begin{array}{c}\text { This variable equals one for firms that have } \\
\text { been sued in any time during the past three } \\
\text { years prior to the litigation year and zero } \\
\text { otherwise }\end{array}$ & $\begin{array}{l}\text { Stanford's Securities } \\
\text { Class Action } \\
\text { Clearinghouse (SCAC) }\end{array}$ & $\begin{array}{l}\text { Gande and } \\
\text { Lewis (2009) }\end{array}$ & + \\
\hline $\mathrm{INST}_{\mathrm{t}-1}$ & $\begin{array}{l}\text { Ratio of the number of shares held by } \\
\text { institutional shareholders at the end of the year } \\
\text { to the total number of shares outstanding }\end{array}$ & Thomson Financial & $\begin{array}{l}\text { Kim and Skinner } \\
(2012)\end{array}$ & + \\
\hline
\end{tabular}


Table 5: Summary statistics

This table provides summary statistics and univariate comparison tests for all firms in our sample and control group. Panel A presents summary statistics for our risk management factor and its components while Panel B presents statistics for our control variables. Specifically, we report information on the mean, median, standard deviation (St. Dev.), 1st quartile (Q1), and 3rd quartile (Q3) of each variable in our sub-sample of sued and non-sued firms. Significance levels are computed for the difference in means (medians) using a t-test (Wilcoxon two-sided t-test) and are indicated by ${ }^{*},{ }^{* *}$, and ${ }^{* * *}$ which denote significance at the $10 \%, 5 \%$, and $1 \%$ level, respectively.

Panel A: Summary statistics for risk management factor and its components

\begin{tabular}{|c|c|c|c|c|c|c|c|c|c|c|}
\hline Variable & \multicolumn{2}{|c|}{ Mean } & \multicolumn{2}{|c|}{ Median } & \multicolumn{2}{|c|}{ St. Dev. } & \multicolumn{2}{|c|}{ Q1 } & \multicolumn{2}{|c|}{ Q3 } \\
\hline Sub-sample & Sued & $\begin{array}{l}\text { Non- } \\
\text { sued }\end{array}$ & Sued & $\begin{array}{l}\text { Non- } \\
\text { sued }\end{array}$ & Sued & $\begin{array}{l}\text { Non- } \\
\text { sued }\end{array}$ & Sued & $\begin{array}{l}\text { Non- } \\
\text { sued }\end{array}$ & Sued & $\begin{array}{l}\text { Non- } \\
\text { sued }\end{array}$ \\
\hline RM_1Y & 0.0231 & $0.4348^{* * *}$ & -0.0321 & $0.2432^{* * *}$ & 1.3718 & 1.6136 & -0.7901 & -0.8512 & 0.9911 & 1.4321 \\
\hline SUITE & 0.2872 & $0.5429^{* * *}$ & 0 & $1^{* * *}$ & 0.4533 & 0.4992 & 0 & 1 & 1 & 1 \\
\hline COMP & 0.4697 & $0.6360^{* * *}$ & 0.3822 & $0.4618^{* * *}$ & 0.5993 & 0.7481 & 0.2238 & 0.3026 & 0.5410 & 0.6647 \\
\hline $\mathrm{XP}$ & 0.0461 & 0.0490 & 0 & 0 & 0.2101 & 0.2163 & 0 & 0 & 0 & 0 \\
\hline REP & 0.0106 & 0.0245 & 0 & 0 & 0.1028 & 0.1549 & 0 & 0 & 0 & 0 \\
\hline TEN & 0.8688 & $1.9429^{* * *}$ & 0 & 0 & 1.9016 & 4.6152 & 0 & 0 & 0 & 2 \\
\hline TOP5 & 0.0709 & $0.1633^{* * *}$ & 0 & $1^{* * *}$ & 0.2572 & 0.3704 & 0 & 0 & 0 & 1 \\
\hline COMMITTEE & 0.5461 & 0.5061 & 1 & 1 & 0.4988 & 0.5010 & 0 & 0 & 1 & 1 \\
\hline COMMITTEE_XP & 0.1312 & $0.2041^{* *}$ & 0 & 0 & 0.3382 & 0.4039 & 0 & 0 & 0 & 0 \\
\hline COMMITTEE_MEET & 2.1277 & 2.0816 & 0 & 0 & 2.9848 & 3.3476 & 0 & 0 & 4 & 6 \\
\hline
\end{tabular}


Panel B: Summary statistics for control variables

\begin{tabular}{|c|c|c|c|c|c|c|c|c|c|c|}
\hline \multirow{2}{*}{$\begin{array}{r}\text { Variable } \\
\text { Sub-sample }\end{array}$} & \multicolumn{2}{|c|}{ Mean } & \multicolumn{2}{|c|}{ Median } & \multicolumn{2}{|c|}{ St. Dev. } & \multicolumn{2}{|c|}{ Q1 } & \multicolumn{2}{|c|}{ Q3 } \\
\hline & Sued & $\begin{array}{l}\text { Non- } \\
\text { sued }\end{array}$ & Sued & $\begin{array}{l}\text { Non- } \\
\text { sued }\end{array}$ & Sued & $\begin{array}{l}\text { Non- } \\
\text { sued } \\
\end{array}$ & Sued & $\begin{array}{l}\text { Non- } \\
\text { sued }\end{array}$ & Sued & $\begin{array}{l}\text { Non- } \\
\text { sued }\end{array}$ \\
\hline ACC_TT & 0.0393 & 0.0160 & 0.0461 & 0.0323 & 0.1155 & 0.0812 & -0.0270 & -0.0232 & 0.1002 & 0.0805 \\
\hline $\mathrm{ACC}_{-}^{-} \mathrm{OP}$ & -0.0067 & -0.004 & -0.0086 & -0.0068 & 0.0563 & 0.0535 & -0.0298 & -0.0158 & 0.0070 & 0.0049 \\
\hline $\mathrm{BON}^{-}$ & 0.1884 & 0.2523 & 0 & 0 & 0.2924 & 0.3359 & 0.5186 & 0 & 0.3194 & 0 \\
\hline AUD & 0.6067 & $0.4500^{* *}$ & 1 & $0^{* *}$ & 0.4912 & 0.5006 & 1 & 0 & 1 & 0 \\
\hline ENT_AGG & 0.1109 & 0.1283 & 0.0636 & 0.0680 & 0.1558 & 0.1876 & 0.0447 & 0.0428 & 0.1125 & 0.1067 \\
\hline ENT_TAIL_I & -0.0353 & -0.0292 & -0.0291 & -0.0241 & 0.0280 & 0.0201 & -0.0427 & -0.0328 & -0.0182 & -0.0169 \\
\hline ENT_TAIL_II & -0.0659 & -0.0668 & -0.0558 & -0.0569 & 0.0276 & 0.0281 & -0.0913 & -0.0924 & -0.0485 & -0.0455 \\
\hline ENT_DOWN & 0.5168 & $0.4185^{* *}$ & 0.3853 & $0.3574^{* *}$ & 0.2880 & 0.1866 & 0.3291 & 0.2801 & 0.7017 & 0.4754 \\
\hline INST & 0.5679 & $0.4722^{* * *}$ & 0.5755 & $0.4963^{* * *}$ & 0.2262 & 0.2182 & 0.4529 & 0.3080 & 0.7035 & 0.6253 \\
\hline LEV_B & 0.9069 & 0.9081 & 0.9175 & $0.9058^{* * * *}$ & 0.0926 & 0.0216 & 0.9065 & 0.8983 & 0.9367 & 0.9223 \\
\hline $\mathrm{LEV}^{-} \mathrm{M}$ & 0.8643 & 0.8532 & 0.9018 & $0.8710^{* * *}$ & 0.1443 & 0.0899 & 0.8514 & 0.8161 & 0.9385 & 0.9039 \\
\hline $\mathrm{LIT}^{-}$ & 0.3371 & $0.1125^{* * *}$ & 0 & 0 & 0.4754 & 0.3180 & 1 & 0 & 1 & 0 \\
\hline ROE & 0.0925 & $0.2433^{* *}$ & 0.1680 & $0.2255^{\text {*** }}$ & 0.7125 & 0.2029 & 0.0788 & 0.1487 & 0.3206 & 0.2993 \\
\hline $\mathrm{ROA}$ & 0.0158 & $0.0206^{* *}$ & 0.0150 & $0.0198^{* * *}$ & 0.0306 & 0.0133 & 0.0054 & 0.0127 & 0.0269 & 0.0261 \\
\hline ROIC & 0.0054 & $0.0347^{* *}$ & 0.0213 & $0.0362^{* * *}$ & 0.1001 & 0.0427 & -0.0135 & 0.0153 & 0.0502 & 0.0515 \\
\hline ROE_SD & 0.1024 & $0.0622^{* *}$ & 0.0677 & $0.0479^{* * *}$ & 0.3834 & 0.0673 & 0.0297 & 0.0221 & 0.1272 & 0.0768 \\
\hline ROA_SD & 0.0101 & $0.0075^{* *}$ & 0.0067 & $0.0043^{* * *}$ & 0.0129 & 0.0231 & 0.0024 & 0.0019 & 0.0117 & 0.0069 \\
\hline ROIC_SD & 0.1022 & $0.0462^{* *}$ & 0.0563 & $0.0332^{* * *}$ & 0.1120 & 0.0609 & 0.0683 & 0.0223 & 0.1328 & 0.0627 \\
\hline TURN & 2.2677 & $1.4193^{* * *}$ & 1.7047 & $1.1179^{* * *}$ & 1.9682 & 1.4159 & 0.8914 & 0.6018 & 2.9965 & 1.6393 \\
\hline SHARE & 0.0079 & 0.0063 & 0.0009 & $0.0015^{* *}$ & 0.0298 & 0.0102 & 0.0004 & 0.0008 & 0.0030 & 0.0069 \\
\hline RET & -0.1825 & -0.0923 & -0.1801 & $-0.0964^{* *}$ & 0.4092 & 0.3790 & -0.5266 & -0.2869 & 0.0624 & 0.1299 \\
\hline RET_SD & 0.3091 & 0.2856 & 0.2894 & $0.2215^{* *}$ & 0.1833 & 0.3037 & 0.2038 & 0.1268 & 0.3834 & 0.3714 \\
\hline
\end{tabular}




\section{Table 6: Correlation matrix}

This table shows the correlation matrix for our dependent variable, risk management factor, and control variables included in our base regression model (i.e., model 1). The numbers below the main diagonal are the Pearson correlations. The SUED dummy takes the value of one if the firm was the defendant in a class action lawsuit in the 1999-2011 period, and zero otherwise. The risk management factor $\left(R M_{-} 1 Y\right)$ is the single factor from principal component analysis with the highest eigenvalue that can explain most of the variation in our risk management proxies. Profitability $(P R O F)$ is net income before taxes plus interest expense divided by total assets. Profitability variation $\left(P R O F \_S D\right)$ is the three-year standard deviation of the firm's annual profitability. Leverage ( $\left.L E V\right)$ is calculated as total assets minus the book value of equity divided by total assets. Share turnover (TURN) is the number of shares traded divided by the total number of shares outstanding calculated based on data for one year prior to the litigation year. Stock return (RET) is the percentage stock return during the year prior to the litigation year. Stock return variation $(R E T S S D)$ is the annualized standard deviation of daily stock returns. The auditor variable $(A U D)$ is a dummy variable that differentiates between firms that are audited by one of the big four audit firms (i.e., PricewaterhouseCoopers, Deloitte \& Touche, Ernst \& Young, and KPMG) and firms that employ some other audit firms. Litigation history (LIT) is a dummy variable that takes on a value of one for firms that have been sued in any time during the past three years prior to the litigation year and zero otherwise. Significance levels are indicated by ${ }^{*},{ }^{* *}$, and ${ }^{* * *}$ which denote significance at the $10 \%, 5 \%$, and $1 \%$ level, respectively.

\begin{tabular}{|c|c|c|c|c|c|c|c|c|c|c|}
\hline & SUED & RM_1Y & PROF & PROF_SD & LEV & TURN & RET & RET_SD & AUD & LIT \\
\hline SUED & 1 & & & & & & & & & \\
\hline RM_1Y & $-0.3313^{* * *}$ & 1 & & & & & & & & \\
\hline PROF & -0.0992 & $-0.0766^{*}$ & 1 & & & & & & & \\
\hline PROF_SD & 0.0723 & -0.1222 & $-0.2262^{* * *}$ & 1 & & & & & & \\
\hline $\mathrm{LEV}^{-}$ & -0.0092 & 0.0461 & $-0.4724^{* * *}$ & 0.0261 & 1 & & & & & \\
\hline TURN & $0.2393^{* * *}$ & $0.3580^{* * *}$ & $-0.2474^{* * *}$ & $0.1647^{* *}$ & 0.0112 & 1 & & & & \\
\hline RET & -0.1133 & $-0.0962^{*}$ & $0.2097^{* * *}$ & $-0.1960^{* *}$ & 0.0058 & $-0.3110^{* * *}$ & 1 & & & \\
\hline RET_SD & 0.0477 & -0.1228 & -0.0707 & $0.5251^{* * *}$ & -0.0603 & 0.0209 & $-0.1572^{* *}$ & 1 & & \\
\hline AUD & $0.1569^{* *}$ & $0.3403^{* * *}$ & -0.0261 & 0.0612 & -0.0489 & $0.4912^{* * *}$ & -0.0898 & -0.0212 & 1 & \\
\hline LIT & $0.2661^{* * *}$ & $0.4455^{* * *}$ & 0.0641 & -0.0270 & 0.0653 & $0.2167^{* * *}$ & $-0.1441^{*}$ & -0.0495 & $0.2880^{* * *}$ & 1 \\
\hline
\end{tabular}




\section{Table 7: Multivariate regression results for one year lagged risk management factor}

This table provides regression results for a series of models in which we consider one year lagged risk management factor and accounting data. Our risk management factor $\left(R M_{-} I Y\right)$ is the single factor from principal component analysis with the highest eigenvalue that can explain most of the variation in our risk management proxies. The total accruals ratio $\left(A C C_{-} T T\right)$ is the ratio of income before extraordinary items minus operating cash flows to total assets. CEO bonus compensation $(B O N)$ is the ratio of the CEO's compensation from bonuses to the CEO's total compensation. The auditor variable $(A U D)$ is a dummy variable that differentiates between firms that are audited by one of the big four audit firms (i.e., PricewaterhouseCoopers, Deloitte $\&$ Touche, Ernst \& Young, and KPMG) and firms that employ some other audit firms. Aggregate risk (ENT_AGG) is the standard deviation of the firm's weekly return minus the S\&P 500's weekly return. Tail risk I (ENT_TAIL_I) is the negative of the firm's average return during the $5 \%$ of days on which the S\&P 500 recorded its poorest returns while Tail risk II (ENT_TAIL_II) is the negative of the average return of the firm during the $5 \%$ of days on which the stock itself recorded its worst performance. Downside risk $\left(E N T \_D O W N\right)$ is defined as the average implied volatility of the put options written on the firm's stock. Institutional ownership (INST) is the ratio of the number of shares held by institutional shareholders at the end of the year to the total number of shares outstanding. Leverage $(L E V)$ is calculated as total assets minus the book value of equity divided by total assets. Litigation history (LIT) is a dummy variable that takes on a value of one for firms that have been sued in any time during the past three years prior to the litigation year and zero otherwise. Profitability $(P R O F)$ is net income before taxes plus interest expense divided by total assets. Profitability variation (PROF_SD) is the three-year standard deviation of the firm's annual profitability. Share turnover (TURN) is the number of shares traded divided by the total number of shares outstanding calculated based on data for one year prior to the litigation year. Shares held by the CEO is (SHARE) defined as the total number of shares held by the CEO divided by the total number of shares outstanding. Stock return $(R E T)$ is the percentage stock return during the year prior to the litigation year. Stock return variation $\left(R E T \_S D\right)$ is the annualized standard deviation of daily stock returns. Significance levels are indicated by ${ }^{*},{ }^{* *}$, and ${ }^{* * *}$ which denote significance at the $10 \%, 5 \%$, and $1 \%$ level, respectively. 


\begin{tabular}{|c|c|c|c|c|c|c|c|c|}
\hline \multirow{2}{*}{ Variable } & \multicolumn{8}{|c|}{ Model } \\
\hline & Model 1 & Model 2 & Model 3 & Model 4.a & Model 4.b & Model 4.c & Model 4.d & Model 5 \\
\hline RM_1Y & $-0.1651^{* * *}$ & $-0.1375^{* * *}$ & $-0.1324^{* * *}$ & $-0.1665^{* * *}$ & $-0.1706^{* * *}$ & $-0.1695^{* * *}$ & $-0.1297^{* * *}$ & $-0.1693^{* * *}$ \\
\hline $\mathrm{ACC}_{-} \mathrm{TT}$ & - & 0.0225 & - & - & - & - & 一 & - \\
\hline $\mathrm{BON}^{-}$ & - & - & $-0.4205^{*}$ & - & - & - & - & - \\
\hline AUD & -0.0056 & 0.1389 & -0.0105 & 0.0030 & 0.0596 & 0.0825 & 0.0151 & 0.0277 \\
\hline ENT_AGG & - & - & - & -0.1704 & - & - & - & - \\
\hline ENT_TAIL_I & - & - & - & - & 0.2174 & - & - & - \\
\hline ENT_TAIL_II & - & - & - & - & - & 1.9295 & - & - \\
\hline ENT_DOWN & - & - & - & - & - & - & 0.0609 & - \\
\hline INST & - & - & - & - & - & - & - & $0.3172^{*}$ \\
\hline LEV & -0.6067 & -0.9614 & -0.2195 & -0.5990 & -0.6221 & -0.5338 & -0.5483 & -0.5024 \\
\hline LIT & $0.3576^{* * *}$ & $0.3775^{* * *}$ & $0.3013^{* *}$ & $0.3860^{* * *}$ & $0.3492^{* * *}$ & $0.3458^{* * *}$ & $0.3612^{* * *}$ & $0.3612^{* * *}$ \\
\hline PROF & -2.6941 & $-4.5356^{*}$ & -0.7066 & -2.8540 & -3.1598 & $-3.2161^{*}$ & -1.2274 & -2.6075 \\
\hline PROF_SD & -0.3662 & -2.3683 & 8.1459 & -0.3964 & -0.3728 & -0.5156 & 4.1125 & -0.0088 \\
\hline TURN & $0.0575^{* *}$ & $0.0464^{*}$ & 0.0436 & $0.0438^{*}$ & 0.0391 & $0.0458^{*}$ & 0.0161 & 0.0468 \\
\hline SHARE & 一 & - & -1.3222 & - & - & - & - & - \\
\hline RET & -0.0175 & -0.0357 & -0.0356 & -0.0306 & -0.0030 & -0.0202 & -0.0528 & 0.0253 \\
\hline RET_SD & 0.0241 & 0.0363 & 0.5309 & 0.0573 & 0.0313 & 0.0106 & 0.3314 & -0.0559 \\
\hline Adjusted $\mathrm{R}^{2}$ & $10.98 \%$ & $12.62 \%$ & $10.99 \%$ & $9.79 \%$ & $10.22 \%$ & $11.10 \%$ & $8.57 \%$ & $12.13 \%$ \\
\hline F-value & $2.99^{* * *}$ & $2.65^{* * *}$ & $2.13^{* *}$ & $2.62^{* * *}$ & $2.61^{* * *}$ & $2.77^{* * *}$ & $1.95^{* *}$ & $2.81^{* * *}$ \\
\hline $\mathrm{N}$ & 170 & 128 & 150 & 166 & 158 & 158 & 112 & 144 \\
\hline
\end{tabular}




\section{Table 8: Multivariate regression results for three-year average risk management factor}

This table provides regression results for a series of models in which we consider three-year average risk management factor and accounting data. Our risk management factor $(R M-3 Y)$ is the single factor from principal component analysis with the highest eigenvalue that can explain most of the variation in our risk management proxies. The total accruals ratio $\left(A C C_{-} T T\right)$ is the ratio of income before extraordinary items minus operating cash flows to total assets. CEO bonus compensation $(B O N)$ is the ratio of the CEO's compensation from bonuses to the CEO's total compensation. The auditor variable $(A U D)$ is a dummy variable that differentiates between firms that are audited by one of the big four audit firms (i.e., PricewaterhouseCoopers, Deloitte $\&$ Touche, Ernst \& Young, and KPMG) and firms that employ some other audit firms. Aggregate risk (ENT_AGG) is the standard deviation of the firm's weekly return minus the S\&P 500's weekly return. Tail risk I (ENT_TAIL_I) is the negative of the firm's average return during the $5 \%$ of days on which the S\&P 500 recorded its poorest returns while Tail risk II (ENT_TAIL_II) is the negative of the average return of the firm during the $5 \%$ of days on which the stock itself recorded its worst performance. Downside risk $\left(E N T \_D O W N\right)$ is defined as the average implied volatility of the put options written on the firm's stock. Institutional ownership (INST) is the ratio of the number of shares held by institutional shareholders at the end of the year to the total number of shares outstanding. Leverage $(L E V)$ is calculated as total assets minus the book value of equity divided by total assets. Litigation history (LIT) is a dummy variable that takes on a value of one for firms that have been sued in any time during the past three years prior to the litigation year and zero otherwise. Profitability $(P R O F)$ is net income before taxes plus interest expense divided by total assets. Profitability variation (PROF_SD) is the three-year standard deviation of the firm's annual profitability. Share turnover (TURN) is the number of shares traded divided by the total number of shares outstanding calculated based on data for one year prior to the litigation year. Shares held by the CEO is (SHARE) defined as the total number of shares held by the CEO divided by the total number of shares outstanding. Stock return $(R E T)$ is the percentage stock return during the year prior to the litigation year. Stock return variation $\left(R E T \_S D\right)$ is the annualized standard deviation of daily stock returns. Significance levels are indicated by ${ }^{*},{ }^{* *}$, and ${ }^{* * *}$ which denote significance at the $10 \%, 5 \%$, and $1 \%$ level, respectively. 


\begin{tabular}{|c|c|c|c|c|c|c|c|c|}
\hline \multirow{2}{*}{ Variable } & \multicolumn{8}{|c|}{ Model } \\
\hline & Model 1 & Model 2 & Model 3 & Model 4.a & Model 4.b & Model 4.c & Model 4.d & Model 5 \\
\hline RM_3Y & $-0.1676^{* * *}$ & $-0.1598^{* * *}$ & $-0.1356^{* *}$ & $-0.1719^{* * *}$ & $-0.1660^{* * *}$ & $-0.1639^{* * *}$ & $-0.1291^{* *}$ & $-0.1112^{* * *}$ \\
\hline $\mathrm{ACC}$ & - & 1.3087 & - & - & - & - & - & - \\
\hline $\mathrm{BON}$ & - & - & -0.0086 & - & - & - & - & - \\
\hline AUD & -0.0156 & 0.0625 & 0.0684 & -0.0276 & -0.0411 & -0.0284 & 0.0024 & 0.0292 \\
\hline ENT_AGG & - & - & - & -0.3484 & - & - & - & - \\
\hline ENT_TAIL_I & - & - & - & - & 1.0310 & - & - & - \\
\hline ENT_TAIL_II & - & - & - & - & - & 1.8483 & - & - \\
\hline ENT_DOWN & - & - & - & - & - & - & 0.1853 & 一 \\
\hline INST & - & - & - & - & - & - & - & $0.1974^{* *}$ \\
\hline LEV & -0.7729 & $-1.4765^{*}$ & 0.0944 & -0.6856 & -0.9743 & -0.9683 & 0.0600 & -0.5305 \\
\hline LIT & $0.3325^{* * *}$ & $0.3803^{* * *}$ & $0.2979^{* *}$ & $0.3236^{* * *}$ & 0.2811 & $0.2834^{* *}$ & $0.3203^{* *}$ & $0.3767^{* * *}$ \\
\hline PROF & -1.2941 & -4.6275 & 0.5115 & -1.5703 & -2.3823 & -2.5072 & 0.1376 & -2.5976 \\
\hline PROF_SD & 0.0474 & -1.9597 & 10.4149 & -1.0755 & -0.4869 & -0.4393 & 2.0210 & 0.7248 \\
\hline TURN'̄ & $0.0721^{*}$ & $0.0739^{*}$ & -0.0002 & $0.0956^{* *}$ & $0.1085^{* *}$ & $0.1063^{* *}$ & 0.0003 & $0.0768^{* *}$ \\
\hline SHARE & - & - & -2.2784 & - & - & - & - & - \\
\hline RET & -0.1713 & -0.0542 & $-0.7007^{*}$ & -0.2430 & -0.1661 & -0.2026 & -0.6060 & 0.0706 \\
\hline RET_SD & -0.0054 & 0.0196 & $0.7076^{*}$ & 0.0688 & -0.0850 & -0.1020 & 0.4615 & -0.1451 \\
\hline Adjusted $\mathrm{R}^{2}$ & $10.62 \%$ & $10.94 \%$ & $11.54 \%$ & $11.90 \%$ & $10.30 \%$ & $10.56 \%$ & $9.33 \%$ & $11.87 \%$ \\
\hline F-value & $2.83^{* * *}$ & $2.41^{* * * *}$ & $2.13^{* *}$ & $2.85^{* * *}$ & $2.49^{* * *}$ & $2.53^{* * *}$ & $1.95^{* *}$ & $2.81^{* * *}$ \\
\hline $\mathrm{N}$ & 170 & 128 & 104 & 152 & 144 & 144 & 102 & 140 \\
\hline
\end{tabular}




\section{Table 9: Predictive ability of models with/without the risk management factor}

This table provides information on the predictive ability of our model with the risk management factor as one of the independent variables and compares it with the corresponding model without that factor. Our risk management factor $\left(R M \_1 Y\right)$ is the single factor from principal component analysis with the highest eigenvalue that can explain most of the variation in our risk management proxies. The auditor variable $(A U D)$ is a dummy variable that differentiates between firms that are audited by one of the big four audit firms (i.e., PricewaterhouseCoopers, Deloitte \& Touche, Ernst \& Young, and KPMG) and firms that employ some other audit firms. Leverage $(L E V)$ is calculated as total assets minus the book value of equity divided by total assets. Litigation history (LIT) is a dummy variable that takes on a value of one for firms that have been sued in any time during the past three years prior to the litigation year and zero otherwise. Profitability $(P R O F)$ is net income before taxes plus interest expense divided by total assets. Profitability variation (PROF_SD) is the three-year standard deviation of the firm's annual profitability. Share turnover (TURN) is the number of shares traded divided by the total number of shares outstanding calculated based on data for one year prior to the litigation year. Stock return $(R E T)$ is the percentage stock return during the year prior to the litigation year. Stock return variation $\left(R E T \_S D\right)$ is the annualized standard deviation of daily stock returns. Accuracy $I$ is the ratio of total number of correct predictions (either sued or not sued) to the total number of observations while Accuracy II is the number of correct predictions of sued firms to the total number of sued firms. Significance levels are indicated by ${ }^{*},{ }^{* *}$, and ${ }^{* * *}$ which denote significance at the $10 \%, 5 \%$, and $1 \%$ level, respectively. 


\begin{tabular}{|c|c|c|c|c|c|c|}
\hline \multirow[b]{2}{*}{ Variable } & \multicolumn{2}{|c|}{2011} & \multicolumn{2}{|c|}{2010} & \multicolumn{2}{|c|}{2009} \\
\hline & $\begin{array}{l}\text { Model with } \\
\text { the Risk } \\
\text { Management } \\
\text { Factor }\end{array}$ & $\begin{array}{l}\text { Model without } \\
\text { the Risk } \\
\text { Management } \\
\text { Factor }\end{array}$ & $\begin{array}{l}\text { Model with } \\
\text { the Risk } \\
\text { Management } \\
\text { Factor }\end{array}$ & $\begin{array}{l}\text { Model without } \\
\text { the Risk } \\
\text { Management } \\
\text { Factor }\end{array}$ & $\begin{array}{l}\text { Model with } \\
\text { the Risk } \\
\text { Management } \\
\text { Factor }\end{array}$ & $\begin{array}{l}\text { Model without } \\
\text { the Risk } \\
\text { Management } \\
\text { Factor }\end{array}$ \\
\hline RM_1Y & $-0.1299^{* *}$ & - - & $-0.1150^{* *}$ & - - & $-0.1063^{* *}$ & - - \\
\hline AUD & 0.0748 & 0.0752 & -0.0504 & -0.0365 & -0.0458 & -0.0378 \\
\hline LEV & -1.0864 & -1.0862 & $-1.4759^{*}$ & $-1.4652^{*}$ & -1.3148 & -1.2202 \\
\hline LIT & $0.3914^{* * *}$ & $0.3112^{* *}$ & $0.3934^{* *}$ & $0.2991^{* *}$ & $0.4043^{* *}$ & $0.3042^{*}$ \\
\hline PROF & -4.2308 & -4.0004 & -4.5634 & -4.2111 & -3.6708 & -3.0838 \\
\hline PROF_SD & -1.8122 & -1.2396 & -0.0425 & 0.2085 & -0.7990 & -1.1094 \\
\hline SHARE & $0.0473^{*}$ & 0.0354 & $0.0890^{* *}$ & $0.0806^{* *}$ & $0.1134^{* *}$ & $0.1114^{* *}$ \\
\hline RET & -0.0661 & -0.0588 & 0.0498 & 0.0588 & 0.2740 & 0.2864 \\
\hline RET_SD & 0.0171 & 0.0366 & -0.1195 & -0.0839 & -0.1145 & -0.0472 \\
\hline Accuracy I & $64.28 \%$ & $57.14 \%$ & $58.33 \%$ & $50 \%$ & $80.95 \%$ & $71.43 \%$ \\
\hline Accuracy II & $62.5 \%$ & $50 \%$ & $50 \%$ & $41.67 \%$ & $90.91 \%$ & $81.81 \%$ \\
\hline
\end{tabular}

